\title{
Desmoglein 2 mutant mice develop cardiac fibrosis and dilation
}

\author{
Claudia A. Krusche $\cdot$ Bastian Holthöfer • Valérie Hofe • Annette M. van de Sandt • \\ Leonid Eshkind • Ernesto Bockamp • Marc W. Merx • Sebastian Kant • \\ Reinhard Windoffer $\cdot$ Rudolf E. Leube
}

Received: 18 August 2010/Revised: 9 March 2011/Accepted: 21 March 2011 /Published online: 1 April 2011

(c) Springer-Verlag 2011

\begin{abstract}
Desmosomes are cell-cell adhesion sites and part of the intercalated discs, which couple adjacent cardiomyocytes. The connection is formed by the extracellular domains of desmosomal cadherins that are also linked to the cytoskeleton on the cytoplasmic side. To examine the contribution of the desmosomal cadherin desmoglein 2 to cardiomyocyte adhesion and cardiac function, mutant mice were prepared lacking a part of the extracellular adhesive domain of desmoglein 2. Most live born mutant mice presented normal overall cardiac morphology at 2 weeks. Some animals, however, displayed extensive fibrotic lesions. Later on, mutants developed ventricular dilation leading to cardiac insufficiency and eventually
\end{abstract}

The authors C.A. Krusche and B. Holthöfer contributed equally.

Electronic supplementary material The online version of this article (doi:10.1007/s00395-011-0175-y) contains supplementary material, which is available to authorized users.

C. A. Krusche $(\bowtie) \cdot$ B. Holthöfer · V. Hofe $\cdot$ S. Kant ·

R. Windoffer · R. E. Leube $(\square)$

Institute of Molecular and Cellular Anatomy, RWTH Aachen

University, Wendlingweg 2, 52074 Aachen, Germany

e-mail: ckrusche@ukaachen.de

R. E. Leube

e-mail: rleube@ukaachen.de

A. M. van de Sandt - M. W. Merx

Division of Cardiology, Angiology and Pneumology, Department of Medicine, University Hospital Düsseldorf, Moorenstr. 5, 40225 Düsseldorf, Germany

L. Eshkind · E. Bockamp

Institute for Toxicology, Medical Centre of the Johannes

Gutenberg-University Mainz, Obere Zahlbacher Str. 67,

55131 Mainz, Germany premature death. Upon histological examination, cardiomyocyte death by calcifying necrosis and replacement by fibrous tissue were observed. Fibrotic lesions were highly proliferative in 2-week-old mutants, whereas the fibrotic lesions of older mutants showed little proliferation indicating the completion of local muscle replacement by scar tissue. Disease progression correlated with increased mRNA expression of c-myc, ANF, BNF, CTGF and GDF15, which are markers for cardiac stress, remodeling and heart failure. Taken together, the desmoglein 2-mutant mice display features of dilative cardiomyopathy and arrhythmogenic right ventricular cardiomyopathy, an inherited human heart disease with pronounced fibrosis and ventricular arrhythmias that has been linked to mutations in desmosomal proteins including desmoglein 2.

Keywords Desmoglein 2 - Desmosome - Mouse model · Cardiomyopathy $\cdot$ ARVC

\author{
Abbreviations \\ ARVC Arrhythmogenic right ventricular \\ cardiomyopathy \\ DSG2 Gene encoding Dsg2 \\ Dsg2 Desmoglein 2 polypeptide
}

\section{Introduction}

The intercalated disc is a complex cell-cell attachment site mediating mechanical and electrical coupling between cardiomyocytes. It consists of adherens junctions, which facilitate the attachment of the actin filament-containing contractile apparatus and desmosomes, which serve as 
anchorage sites for desmin intermediate filaments. Desmosomes are symmetric multiprotein assemblies with their halves interconnected to transmit forces between adjacent cells (reviews in $[19,21,28]$ ). At the core are calciumdependent adhesion proteins of the cadherin type that are grouped into two families, the desmocollins and desmogleins. In the heart, desmoglein 2 (Dsg2) and desmocollin 2 are by far the most prominent, if not sole desmosomal cadherins [28]. These polypeptides interact in cis and trans forming homo- and heteropolymers via their extracellular domains EC1-EC4, the configuration of which is influenced by calcium ion binding $[13,55,59,60]$. It is assumed that the insertion of tryptophane 2 into a hydrophobic pocket of the EC1 domain and EC1-EC2 interactions are important for multimerization and engagement in zipperlike transcellular arrangements (e.g., [7] for C-cadherin), which is supported by ultrastructural analyses $[1,23]$ and antibody localization studies [53]. Desmosomal cadherins are connected to cytoplasmic linker molecules, which are localized to the desmosomal plaque. These linkers include plakoglobin and the cell-type specifically expressed plakophilins (cf. [19, 21, 28]). In the case of plakoglobin, direct desmosomal cadherin binding sites have been identified (e.g., [12]). Desmoplakin, a member of the plakin cytolinker family, is another major component of the desmosomal plaque. It binds to plakophilins and mediates intermediate filament attachment to desmosomal junctions $[19,21,28]$.

Mutations of the genes encoding Dsg2, desmocollin 2, plakoglobin, plakophilin 2 and desmoplakin are found in approximately $50 \%$ of patients with arrhythmogenic right ventricular cardiomyopathy (ARVC) [2, 24, 57]. Thus, ARVC is considered to be a disease of the desmosome, although other factors are also implicated $[5,20,24,39$, 51, 58]. ARVC occurs at a frequency of $1: 1,000$ to $1: 5,000[3,9]$ and leads to heart failure or sudden cardiac death in young adults. Excessive dilation, predominantly of the right ventricle, progressive fibrofatty replacement of cardiomyocytes and arrhythmias are the main features of the disease (recent reviews [24, 57, 61]). Especially in patients carrying mutations in the desmoplakin and DSG2 genes, the left ventricle is also severely affected [17]. In addition, the V55M missense mutation of the DSG2 gene predisposes to dilative cardiomyopathy [48].

To analyze the impact of the adhesive extracellular Dsg2 domains in demososme-related heart function, mouse strains were established lacking exons 4-6 of the DSG2 gene, which code for major parts of the EC1/EC2 domains. Homozygous mutant mice presented heart disease with necrotic cell death of cardiomyocytes, cardiac fibrosis and dilation of heart chambers leading to cardiac dysfunction.

\section{Materials and methods}

\section{DNA cloning}

All synthetic oligonucleotides are listed in Table 1. A targeting construct was prepared to conditionally delete exons 3 and 4 of murine DSG2. First, the $5^{\prime}$-homology region between introns 3 and 6 was subcloned as a 5,483 bp HindIII-fragment from phage $\lambda \mathrm{Mg} 1$ (cf. [15]) into pBluescript $\mathrm{KS}(+)$ resulting in clone 3001. A $5^{\prime}$-loxP-site was introduced by insertion of annealed oligomers loxP-f/ loxP-r into the NheI-site of intron 3 (clone 3007). A second $X h o I-s i t e$ was then introduced by ligating annealed linkers Eco-Xho-Bst-f/Eco-Xho-Bst-r into the EcoRI- and BstXIsites of clone 3007 (clone 3010). For cloning the $3^{\prime}$-arm, pBluescript II_SK(+) was first modified by inserting annealed linkers 03-51pBS2SK-EI+Sph-a/03-51pBS2SK$\mathrm{EI}+\mathrm{Sph}-\mathrm{b}$ into the EcoRI-site without reconstituting it (clone 3000). Then, the $\sim 4.6 \mathrm{~kb}$ HindIII-fragment of $\lambda \mathrm{Mg} 1$ was cloned into clone 3000 producing clone 3004 . To afford the usage of a $5^{\prime}$-external probe that had been used previously for Southern blot analyses [15], the SphIsite at the $3^{\prime}$-end of clone 3004 was removed by blunt-end ligation after digestion with Bst1107I and SmaI resulting in clone 3008. A construct with the neomycin-resistance cassette (NFL) under control of the phosphoglycerate kinase promoter and flanked by two directed FRT-sites and an additional loxP-site at the $3^{\prime}$-end was provided by Dr. Gale Martin. It was used for PCR-amplification with primers 05-251-Eco-PGK-Neo-f and 05-252-Eco-PGKNeo-r, which introduced EcoRI-sites at either end. The $E c o$ RI-endowed DNA was thereafter ligated into the unique EcoRI-site of exon 6 in clone 3008, thereby creating clone 3009. Clones 3009 and 3010 were then digested with $X h o I$ and the appropriate genomic fragments were ligated rendering the final targeting construct (clone 3011).

Homologous recombination in embryonic stem cells and preparation of transgenic strains

NotI-linearized clone 3011 was transfected into embryonal stem cell strain W9.5 [56] by electroporation (single pulse, $500 \mu \mathrm{F}, 0.24 \mathrm{kV}$ ). G418-resistant colonies were isolated and subjected to Southern blot analyses. To this end, EcoRVdigested and gel electrophoretically separated DNA was blotted onto nylon membranes and hybridized with two external and one internal (neomycin) probes that were generated by PCR. Primers 03-66_5ext_for/03-67_5ext_rev were used for the $5^{\prime}$-external probe, primers 03-54_3ext_for/ 03-72_3ext_rev2 for the $3^{\prime}$-external probe, and primers 03-70_NeoProbe_for/03-71_NeoProbe_rev for the internal neomycin probe (Table 1). The PCR products were labeled with ${ }^{32} \mathrm{P}$-dATP by random primed oligo labeling 
Table 1 List of synthetic oligonucleotides

\begin{tabular}{|c|c|}
\hline Name & Sequence $\left(5^{\prime}-3^{\prime}\right)$ \\
\hline loxP-f & CTAGAAGCTTATAACTTCGTATAATGTATGCTATACGAAGTTATGATATC \\
\hline loxP-r & CTAGGATATCATAACTTCGTATAGCATACATTATACGAAGTTATAAGCTT \\
\hline Eco-Xho-Bst-f & AATTCCGGCTCGAGATACCGCG \\
\hline Eco-Xho-Bst-r & GTATCTCGAGCCGG \\
\hline 03-51pBS2SK-EI+Sph-a & AGCTTGATATCGCATGCCTGCA \\
\hline 03-51pBS2SK-EI+Sph-b & GGCATGCGATATCA \\
\hline 05-251-Eco-PGK-Neo-f & GCCGGAATTCGCTGCGATTATAGGCCTGAG \\
\hline 05-252-Eco-PGK-Neo-r & GATCGAATTCGCGGGGATAATACGACTC \\
\hline $03-57 b$ & GATCAGCAGCCTCTGTTCC \\
\hline 03-58_3'rev & GTGTCACCAGGGATAGTC \\
\hline 03-66_5ext_for & GATGTGGGAGGCTTAAGAG \\
\hline 03-67_5ext_rev & GTGCTGCGACCCTTTAATC \\
\hline 03-54_3ext_for & AGCATGCATAGAGGCAAATTC \\
\hline 03-72_3ext_rev2 & CTGCCATTCCAGGAAATGC \\
\hline 03-70_NeoProbe_for & AGGCTATTCGGCTATGAC \\
\hline 03-71_NeoProbe_rev & GAGCTGGCCCTTAATTTG \\
\hline $07-12-f$ & CCAGAAAGAACCCGATTG \\
\hline $07-13-\mathrm{r}$ & GATCCGCATGACTTCTAC \\
\hline 05-31-GAPDH-f & ATGAGCCCTTCCACAATG \\
\hline 05-32-GAPDH-r & TCCACTCACGGCAAATTC \\
\hline HMBS-f & TCCCTGAAGGATGTGCCTAC \\
\hline HMBS-r & AAGGGTTTTCCCGTTTGC \\
\hline ANF-f & CACAGATCTGATGGATTTCAAGA \\
\hline ANF-r & ССТCATCTTCTACCGGCATC \\
\hline BNF-f & GTCAGTCGTTTGGGCTGTAAC \\
\hline BNF-r & AGACCCAGGCAGAGTCAGAA \\
\hline$c-m y c-f$ & CCTAGTGCTGCATGAGGAGA \\
\hline c-myc-r & TCTTССТСАТСТТСТTGСТСТТС \\
\hline CTGF-f & TGACCTGGAGGAAAACATTAAGA \\
\hline CTGF-r & AGCCCTGTATGTCTTCACACTG \\
\hline GDF15-f & GAGCTACGGGGTCGCTTC \\
\hline GDF15-r & GGGACCCCAATCTCACCT \\
\hline RGS2-f & GAGAAAATGAAGCGGACACTCT \\
\hline RGS2-r & TTGCCAGTTTTGGGCTTC \\
\hline$\beta \mathrm{MHC}-\mathrm{f}$ & TGAAGCTGACGCAGGAGAG \\
\hline$\beta \mathrm{MHC}-\mathrm{r}$ & TGAGTGCATTTAACTCAAAGTCCT \\
\hline
\end{tabular}

(Stratagene). Cell clones with correct recombination were used to prepare transgenic animals (cf. [15]). Chimeric males were backcrossed with $\mathrm{C} 57 \mathrm{BL} / 6 \mathrm{~J}$ females and the darkhaired offspring was genotyped. To remove the NFL-cassette, transgenic animals were crossed with FLP $^{\mathrm{e}}$ deleter mice [49]. FLP-mediated recombination was assayed by PCR (primers 03-57b and 03-58_3'rev; Table 1) and Southern blot analyses. Animals with correctly recombined alleles were intercrossed with the constitutively Creexpressing "ActCre" strain FVB/N-TgN(ACTB-Cre)2Mrt from Jackson Laboratories [38] to generate constitutively mutant animals.
For experimental analyses, heterozygous animals were crossed to produce wild-type and heterozygous littermate controls. Unfortunately, mutant offspring was often absent because of the small average litter size of six to eight animals and the approximately $70 \%$ reduction of mutant animals due to intrauterine lethality. As an alternative, heterozygous females were crossed with homozygous males, which was more efficient but lacked wild-type controls. Consequently, in the experiments, age-matched controls had to be used from parallel breedings. Analyzed mice still possess a mixed genetic background. To reduce genetic variability, mutant mice were backcrossed with C57BL/6J mice. 


\section{RT-PCR}

The sequences of all primers are listed in Table 1. For analysis of DSG2 mRNA expression, RNA was isolated from snap frozen heart tissue (RNeasy-Kit, Qiagen, Hilden, Germany). As much as $0.5 \mu \mathrm{g}$ of total RNA was transcribed with Omniscript reverse transcriptase (Qiagen) and $1 / 4$ of the cDNA was used as template for secondary strand synthesis with primers 07-12-f and 07-13-r, generating fragments of either $210 \mathrm{bp}$ (recombined) or $686 \mathrm{bp}(\mathrm{wt})$. GAPDH was used as control (primers 05-31-GAPDH-f and 05-32-GAPDH-r).

For all other mRNA analyses, total RNA was isolated with the High Pure RNA Tissue Kit (Roche, Mannheim, Germany); $25 \mathrm{mg}$ tissue was homogenized with a glassTeflon homogenizer in $900 \mu \mathrm{l}$ lysis-/binding buffer and subjected to extraction with phenol/chloroform/isoamyl alcohol (Applied Biosystems, Darmstadt, Germany). As much as $1 \mu \mathrm{g}$ of the affinity column-purified RNA was reverse transcribed into cDNA using the Transcriptor First Strand cDNA Synthesis Kit (Roche) with the oligo-(dT) 15 primer.

Real-time PCR was performed with a LightCycler (Roche) using the LightCycler TaqMan Master Kit (Roche). Forward and reverse primers and corresponding TaqMan probes were selected with the help of the Universal ProbeLibrary Assay Design Center (Roche). They are listed in Table 1 as the following pairs HMBS-f/HMBS-r (UPL\#79), ANF-f/ANF-r (UPL-\#25), BNF-f/BNF-r (UPL\#71), c-mycf/c-myc-r (UPL\#77), CTGF-f/CTGF-r (UPL\#71), GDF15-f/ GDF15-r (UPL\#62), RGS2-f/RGS2-r (UPL\#6), and $\beta$ MHC$\mathrm{f} / \beta \mathrm{MHC}-\mathrm{r}$ (UPL\#85). PCR programs were operated by the LightCycler Software Version 3.5. cDNA $(2 \mu \mathrm{l})$ prepared from $100 \mathrm{ng}$ total RNA was used in each PCR with only water and 100 ng RNA as negative controls. HMBS was used as housekeeping control [22]. Each tissue sample was examined in duplicate. To determine PCR efficiency, a coefficient file was created for each target cDNA and the housekeeping control. Quantitative analyses of cardiac target mRNA expression were performed with the RelQuant Software, Version 1.01 (Roche).

\section{Histology and immunohistochemistry}

Hearts were fixed in PBS containing 4\% formaldehyde, washed and embedded in paraffin; $8-\mu \mathrm{m}$ thick tissue sections were stained with hematoxylin/eosin, Kossa and Heidenhein (azan).

For immunohistochemistry, $5-\mu \mathrm{m}$ thick paraffin sections were prepared. The sections were rehydrated, heated in citrate buffer (pressure cooker, $121^{\circ} \mathrm{C}, 3 \mathrm{~min}$ ), cooled down for $20 \mathrm{~min}$ and incubated with primary antibodies against the extracellular anchor and EC4 domains of murine Dsg2 1:500 or 1:1,000 [50] and desmoplakin (1:1,000 or 1:2,000, Progen, Heidelberg, Germany) overnight at $4^{\circ} \mathrm{C}$. After washing in $50 \mathrm{mM}$ Tris/ $\mathrm{HCl}, 0.3 \mathrm{M}$ $\mathrm{NaCl}, 0.05 \%$ Tween $20, \mathrm{pH} 7.5$, the sections were incubated for $1 \mathrm{~h}$ at room temperature with the secondary antibodies (Alexa488-conjugated goat anti rabbit antibodies [1:500] and Cy3-conjugated affinity purified goat anti-guinea pig antibodies [1:400; both from Dianova, Hamburg, Germany]). After three washing steps, autofluorescence was quenched with $0.1 \%$ Sudan black in $70 \%$ ethanol (30 min). The sections were counterstained with DAPI. Fluorescence micrographs were recorded with an LSM710 DUO (Zeiss, Jena, Germany). For quantification, non-saturating dilution ranges were determined for the primary antibodies. Quantification of intercalated disc staining was done for 40 intercalated discs per animal using the ZEN 2009-Software (Zeiss, Jena, Germany). The ratio of Dsg2- to desmoplakin-fluorescence was calculated for each intercalated disc and the mean value of the ratio of all intercalated discs of each studied animal was determined.

Peroxidase reaction was used for detection of $\mathrm{Ki} 67$ (rabbit mAb, Medac, Wedel, Germany) and cleaved caspase 3 (Cell Signaling Technology, Danvers, MA). Bound primary antibodies were detected with the ZytoChemPlus HRP Polymer anti-Mouse/Rabbit Kit (Zytomed Systems, Berlin, Germany). Paraffin sections of 5- $\mu \mathrm{m}$ thickness were deparaffinized in xylene and rehydrated in a graded alcohol series. During rehydration, the activity of the endogenous peroxidase was blocked by treating sections with $3 \% \mathrm{H}_{2} \mathrm{O}_{2}$ in $70 \%$ ethanol for $10 \mathrm{~min}$ in the dark. Antigen retrieval was achieved by incubating sections in $10 \mathrm{mM}$ citrate buffer ( $\mathrm{pH} \mathrm{6.0)}$ at $94^{\circ} \mathrm{C}$ for $40 \mathrm{~min}(\mathrm{Ki} 67)$ or in a pressure cooker for $3 \mathrm{~min}$ at $121^{\circ} \mathrm{C}$ (cleaved caspase-3). Cooled down sections were treated with blocking solution of the HRP Polymer Kit. Then, sections were incubated for $2 \mathrm{~h}$ at room temperature with the Ki67-antibody (1:200) or overnight at $4^{\circ} \mathrm{C}$ with the cleaved caspase 3-antibody (1:300). After subsequent washing, the sections were covered with the HRP-polymer for $30 \mathrm{~min}$. The AEC Substrate Kit (Invitrogen, Karlsruhe, Germany) was applied to visualize the immunoreaction and sections were counterstained with hematoxylin. The percentage of Ki67positive interstitial cells was counted by two independent and blinded observers (CAK and SK). The percentage of Ki67-positive interstitial cells was assessed in three to four randomly chosen areas of the right and left ventricular wall, as well as in the septum at a magnification of $400 \times$.

Cell fractionation and immunoblotting

Fresh tissue fragments were minced by extensive homogenization in extraction buffer I (10 mM Tris- $\mathrm{HCl}, \mathrm{pH} 8$, $2 \mathrm{mM} \mathrm{MgCl}_{2}, 10 \mathrm{mM} \mathrm{KCl}, 0.1 \% \mathrm{SDS}, 0.05 \% \mathrm{PMSF}$ 
supplemented with one tablet Complete mini (Roche, Mannheim, Germany) per $10 \mathrm{ml}$ buffer) at $4^{\circ} \mathrm{C}$. After shaking for $1 \mathrm{~h}$ at $4^{\circ} \mathrm{C}$, the homogenate was centrifuged at $17,000 \times g$ for $25 \mathrm{~min}$ at $4^{\circ} \mathrm{C}$. The cytosolic supernatant fraction was removed and the pellet was washed three times with extraction buffer. The pellet was then dissolved by shaking in extraction buffer I supplemented with $2 \%$ SDS for $2 \mathrm{~h}$ at $4^{\circ} \mathrm{C}$. After centrifugation $(17,000 \times g, 25 \mathrm{~min}$, $4^{\circ} \mathrm{C}$ ), the supernatant was used for immunoblotting. Protein concentration was determined by Lowry assay (Roth, Karlsruhe, Germany). Proteins were separated by standard SDS polyacrylamide gel electrophoresis and blotted onto PVDF membranes. Antibodies against Dsg2 (rabbit polyclonal 1:1,000; [50]), $\beta$-actin (rabbit polyclonal, A2066, 1:4,000, Sigma, Steinheim, Germany), desmocollin 2 (goat; 1:200; Santa Cruz Biotechnology, Santa Cruz, USA) and desmoplakin (mouse; Progen, Heidelberg, Germany) were diluted in TBST supplemented with 5\% BSA and incubated with the membrane overnight at $4^{\circ} \mathrm{C}$. After three washes in TBST, the membrane was incubated for $1 \mathrm{~h}$ with HRP-coupled secondary antibodies from DAKO (diluted 1:3,000 in TBST containing 5\% milk powder). The ECL system was used for HRP detection (GE Healthcare, Freiburg, Germany).

\section{Echocardiography}

Cardiac images were acquired using a Vevo770 high-resolution ultrasound scanner with $30-\mathrm{MHz}$ linear transducer (VisualSonics Inc.). Echocardiography was performed under slight mask anesthesia by an inhaled mixture of $1.5 \%$ (v/v) isoflurane and $100 \%$ oxygen. ECGs were obtained with built-in ECG electrode-contact pads. Body temperature was maintained at $37^{\circ} \mathrm{C}$ by a heating pad. All hair was removed from the chest using a chemical hair remover (Nair; Carter-Horner; Mississauga, Canada). Aquasonic 100 gel (Parker Laboratories, Hellendoorn, The Netherlands) from which air bubbles had been expelled was applied to the thorax surface to optimize the visibility of the cardiac chambers. Parasternal long-axis and short-axis views were acquired. Image data obtained from multiple cardiac cycles were retrospectively assembled into a representative image sequence of over 100 images per cardiac cycle using the ECG-based Kilohertz Visualization (EKV) capability of the Vevo770 scanner. The EKV images are synchronized with respect to the ECG signal. Left ventricular (LV) end-systolic and end-diastolic volumes (ESV and EDV) were calculated by identification of frames with maximal and minimal cross-sectional area and width. The system software employs a formula based on a cylindrichemiellipsoid model [66]. LV ejection fraction (LVEF), cardiac output (CO), stroke volume (SV) and fractional area change (FAC) were calculated from volume data. M-mode recordings were analyzed for wall thicknesses and chamber dimensions. Fractional shortening (FS) was assessed as a measure of left ventricular systolic function. The Doppler transducer was positioned over the apex (apical four-chamber view) for sampling of the mitral flow wavefrom at the tips of the mitral valves. LV diastolic function was evaluated from the $E / A$ ratio of Doppler tracings, where $E$ is the peak velocity of early diastolic ventricular filling, and $A$ is the peak velocity of late filling associated with atrial contraction. A single ultrasound session ranged from 15 to $30 \mathrm{~min}$ per mouse.

Hemodynamic measurement of left ventricular function and ECG measurements

Invasive hemodynamics were assessed using a 1.4F Millar pressure-volume catheter (SPR-839, Millar Instrument, Houston, Texas) placed into the left ventricle through the right carotid artery. After surgical instrumentation, data were analyzed with the IOX Software (EMKA) to calculate left ventricular developed pressure (LVDP), and the first derivatives of left intraventricular pressure (rate of pressure development $+\mathrm{d} P / \mathrm{d} t_{\max }$ and rate of pressure decrease $\left.\mathrm{d} P / \mathrm{d} t_{\text {min }}\right)$. Cardiac contractility index was calculated as $+\mathrm{d} P / \mathrm{d} t_{\max }$ normalized for the respective LVDP. Relaxation index was calculated as the ratio of $-\mathrm{d} P / \mathrm{d} t_{\min }$ to respective LVDP [40]. To assess the catecholamine responsiveness, cardiac variables were recorded under continuous norepinephrine administration $(0.4 \mu \mathrm{g} / \mathrm{kg} / \mathrm{min}$, i.p.). For ECG measurements, four lead surface ECGs were recorded before and during norepinephrine administration. Therefore, ECG electrodes were attached to each limb. The resulting ECGs were analyzed with the IOX Software (EMKA). At the end of the experiments, mice were killed by cervical dislocation.

\section{Statistical analysis}

Results are presented as mean $\pm \mathrm{SD}$ (echocardiography) or as mean \pm SEM (all other assessments). In cases, in which two groups were compared (echocardiography and RTPCR of 2-week-old mice), data were analyzed by the unpaired Student's $t$ test. $P$ values $<0.05$ were considered to be statistically significant. To analyze the results of three experimental groups, one way ANOVA and post hoc Bonferroni's multiple comparison tests were used.

\section{Results}

Generation of DSG2-mutant mice

A targeting construct was prepared for inducible deletion of exons 4-6 of murine DSG2 (Fig. 1a). This mutation 
does not disrupt the reading frame and encodes mutant Dsg2 (Dsg2 $\left.{ }^{\mathrm{mt}}\right)$ that lacks a substantial segment of the EC1EC2 domains, which are believed to participate in homoand heterophilic desmosomal cadherin interactions (Fig. 1b; cf. [28, 59]). Transgenic mice were prepared from embryonal stem cells after homologous recombination of the targeting construct. The neomycin-resistance cassette was then removed with the help of $\mathrm{Flp}^{\mathrm{e}}$ deleter mice (Fig. 1a) [8]. The resulting DSG2 $2^{\text {loxP/loxP }}$ offspring presented no obvious phenotypic deficiency. To investigate the consequences of constitutive DSG2 mutation, DSG2 $2^{\text {loxP }}$ animals were crossed with transgenic mice producing Crerecombinase under $\beta$-actin promoter control [38]. This led to deletion of exons 4-6 of DSG2 in germ cells and subsequent transmission of the mutated allele to the offspring. In contrast to the previously described DSG2 null mutants lacking exons 7 and 8, all of which died around implantation [15], approximately a third of the DSG2 $2^{\mathrm{mt} / \mathrm{mt}}$ mice lacking exons 4-6 were born apparently healthy, whereas the rest died during intrauterine development. DSG2 ${ }^{\mathrm{mt}}$
A cloning strategy

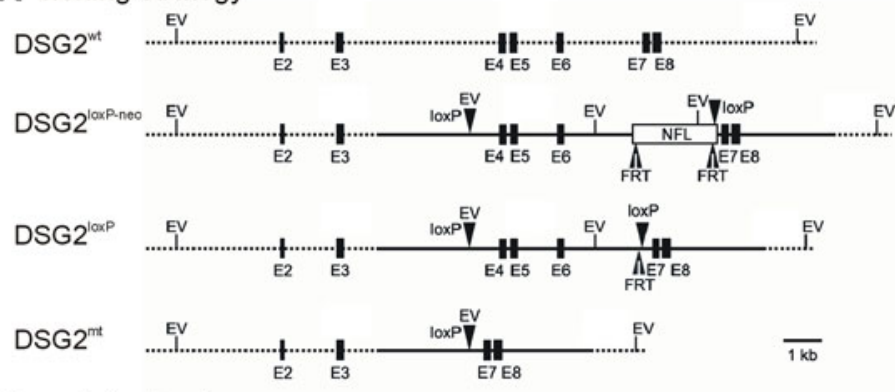

B protein structure

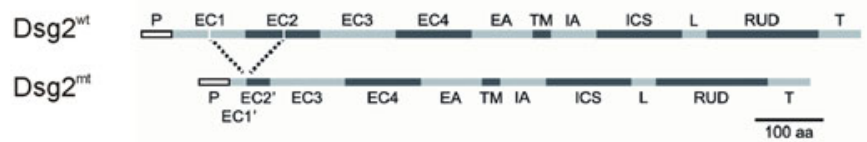

D protein expression

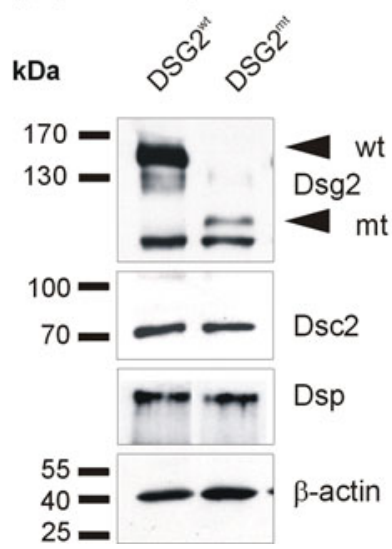

E protein localization
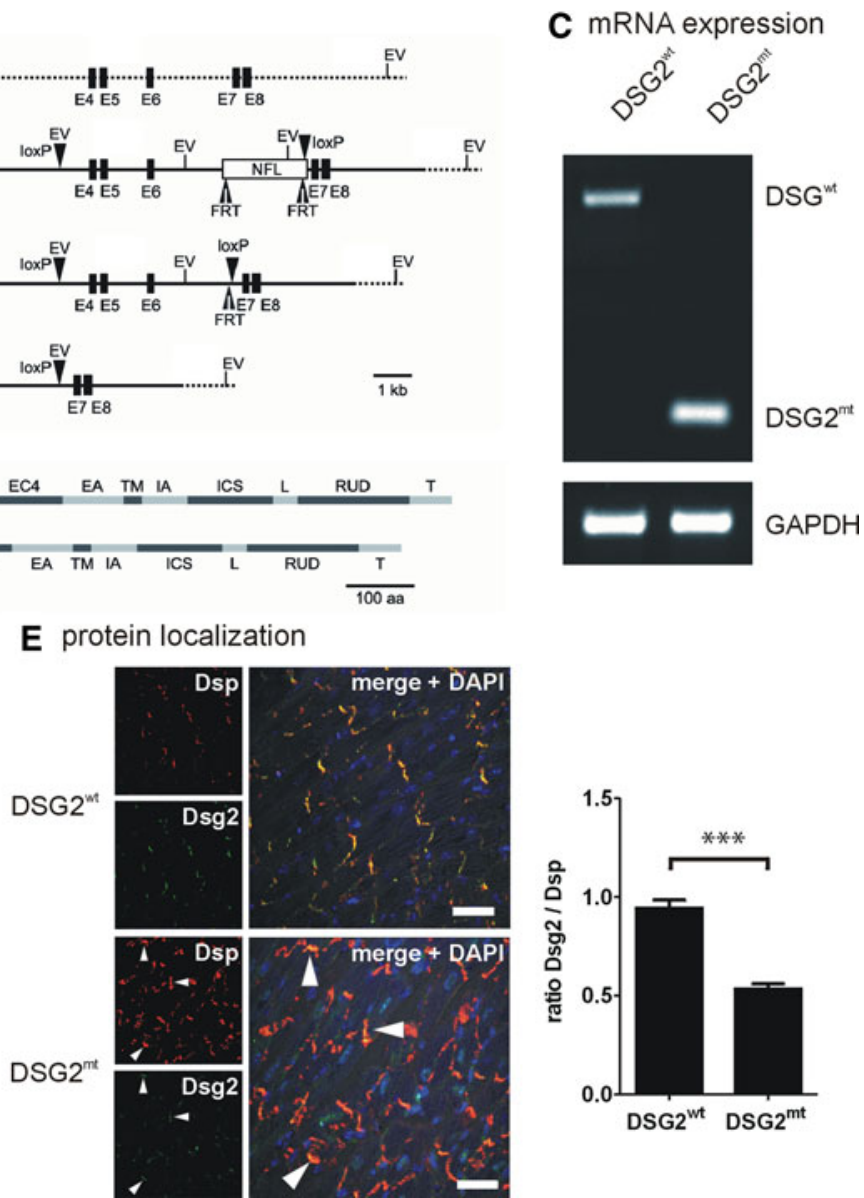

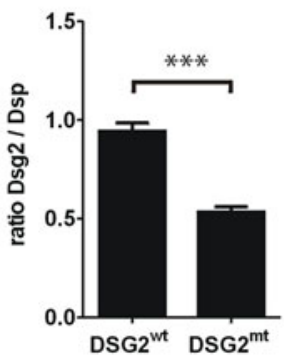

the repeated unit domain $R U D$ and the carboxyterminal tail $T$. c Detection of mutated DSG2 mRNA. RNA was prepared from DSG2 wild-type and mutant mice (DSG2 ${ }^{\mathrm{wt}}$, DSG2 ${ }^{\mathrm{mt}}$ ). GAPDH mRNA was amplified as control. d Analysis of Dsg2 expression by immunoblotting shows a protein band at $\sim 160 \mathrm{kDa}$ in the DSG2 $2^{\mathrm{wt} / \mathrm{wt}}$ and of $\sim 110 \mathrm{kDa}$ in DSG2 ${ }^{\mathrm{mt} / \mathrm{mt}}$ mice. The significant difference in mobility is due to deletion of the single glycosylation site. The calculated molecular weight for wild-type Dsg2 is 122,398 and for mutant Dsg2 104,703. Desmocollin 2 (Dsc2), desmoplakin (Dsp) and $\beta$-actin served as loading controls. e Immunohistochemistry reveals correct targeting of $\mathrm{Dsg}^{\mathrm{mt}}$ to intercalated discs (arrowheads), although expression levels are reduced in $\mathrm{DSG} 2^{\mathrm{mt} / \mathrm{mt}}$ mice (same magnification in all images; scale bar, $20 \mu \mathrm{m}$ ). The quantification was done for four wild-type and four mutant 2-week-old littermates from two litters analyzing the ratio of Dsg2 to desmoplakin fluorescence for 40 intercalated discs in each animal 
mRNA and Dsg $2^{\mathrm{mt}}$ protein are produced in these mice (Fig. 1c, d). Furthermore, Dsg $2^{\mathrm{mt}}$ is located in intercalated discs (Fig. 1e). Dsg2 ${ }^{\mathrm{mt}}$ expression, however, is considerably lower than that of the wild type (Fig. 1d, e).

Cardiac dilation, enlargement and functional deficiencies in DSG2-mutant mice

Echocardiography was performed in 15- to 26-week-old male animals (summary of all results in Table 2). DSG2 $2^{\mathrm{mt} / \mathrm{mt}}$ mice exhibited dilation of the left ventricle (increased diameters in M-mode in Fig. 2a, b) and an elevated enddiastolic volume (Table 2). Elevated end-diastolic volume indicated reduced ventricular compliance. In accordance, early left ventricular filling had a tendency to be slower in $\mathrm{DSG} 2^{\mathrm{mt} / \mathrm{mt}}$ mice (mitral valve E-wave peak), whereas late diastolic blood flow velocity across the mitral valve was significantly reduced (mitral valve A-wave peak). Consequently, the E-wave to A-wave (E/A) ratio was significantly increased in the mutants, indicating impaired ventricular filling. In addition, systolic left ventricular diameter and systolic left ventricular end volume were increased in mutants indicating altered systolic function. Furthermore, ejection fraction, cardiac output and fractional shortening were all reduced (Table 2). Heart rates were comparable between wild type and mutants. Hemodynamic parameters were invasively examined by micro-conductance catheter to complement non-invasive echocardiography (see Table 2). In agreement with the impaired systolic function observed by echocardiography, left ventricular developed pressure (LVDP), the maximal rate of left ventricular pressure change $\left(\mathrm{d} P / \mathrm{d} t_{\max }\right)$, a parameter of cardiac contractility and the contractility index [40] were decreased in DSG $2^{\mathrm{mt} / \mathrm{mt}}$ mice (Table 2). Subjecting animals to stress by treatment with norepinephrine demonstrated that mutant hearts were still responsive, resulting in increase of $\mathrm{LVDP}, \mathrm{d} P / \mathrm{d} t_{\max }$ and contractility index, albeit not to the extent of their wild-type counterparts (Table 2). Reflecting diastolic dysfunction, left ventricular relaxation was significantly impaired with reduced $-\mathrm{d} P / \mathrm{d} t_{\min }$ and relaxation index. Under norepinephrine stimulation, the mutant mice developed ventricular arrhythmias, e.g., ventricular extrasystoles, as well as atrial arrhythmias and repolarization abnormalities (Fig. 2f). One of the mutant animals died during anesthesia. ECG alterations were not recorded in any of the age- and sex-matched wild-type animals in the presence of norepinephrine (Fig. 2e).

Anatomically, dilation of both ventricles and in some cases also dilated atria were readily apparent in dissected female and male mutants (Figs. 2d, 3a, b). Furthermore, heart weight was significantly increased (Table 2). In one case of sudden death, rupture of the right ventricle was detected. Anatomical, histological and clinical parameters did not change upon successive inbreeding and backcrossing against $\mathrm{C} 57 \mathrm{BL} / 6 \mathrm{~J}$ (online resource 1 and 2; unpublished data).

Development of pronounced fibrosis in DSG2-mutant mice

In dissected hearts of mutant mice, fibrotic lesions of various size and different shapes, often in the form of striations, were frequently seen. In some instances, the entire ventricular wall was completely replaced by fibrotic scar tissue resulting in substantial wall thinning (e.g., Fig. 4b, d). Kossa-positive calcifications were often found in fibrotic lesions and scars (Fig. 3c). Furthermore, groups of cardiomyocytes embedded in fibrous tissue and cardiomyocytes with dysmorphic nuclei were noted (Fig. 3d). Histological analyses further revealed different degrees of fibrosis in both ventricular walls and the septum (Fig. 4b, d, f). Staining with azan and anti-vimentin antibodies further supported these findings (e.g., Fig. 4h, j). Extensive infiltrates of immune cells were not seen except for scattered immune cells in a few regions.

Next, proliferation of interstitial cells faraway from fibrotic lesions and proliferation within fibrotic lesions was studied at 2, 8 and 13 weeks by Ki67 immunohistochemistry (Fig. 5). No differences in interstitial cell proliferation were detectable between DSG $2^{\mathrm{wt} / \mathrm{wt}}, \mathrm{DSG} 2^{\mathrm{wt} / \mathrm{mt}}$ and DSG $2^{\mathrm{mt} / \mathrm{mt}}$ at 2 weeks (Fig. $5 \mathrm{a}-\mathrm{c}$ ). At 8 weeks, the proliferation index of interstitial cells was elevated in all segments of the ventricular walls of DSG $2^{\mathrm{mt} / \mathrm{mt}}$ mice compared to DSG2 ${ }^{\mathrm{wt} / \mathrm{wt}}$ animals $(P<0.05$; Fig. $5 \mathrm{~d}-\mathrm{f}, \mathrm{k}, 1)$. Then, at 13 weeks, the percentage of proliferating cells did not differ between mutant and wild-type animals anymore (Fig. 5g-i).

Contiguous fibrotic lesions were examined next. A subset of DSG $2^{\mathrm{mt} / \mathrm{mt}}$ mice presented extensive lesions with necrotic calcinosis already at 2 weeks (Fig. 6c, f). Furthermore, cells expressing activated caspase- 3 were also observed indicating apoptotic cell death (Fig. 6i). Significantly elevated Ki67-staining was detected within these lesions (54.4 $\pm 5.6 \%$; Fig. $5 \mathrm{~m}$ ) in comparison to interstitial cells in areas away from the lesion or in age-matched $\mathrm{DSG} 2^{\mathrm{wt} / \mathrm{wt}}$ and DSG2 ${ }^{\mathrm{wt} / \mathrm{mt}}$ hearts $(P<0.0001)$. Of note, the number of proliferating cells within such lesions was significantly higher in 2-week-old than in 8- and 13-week-old animals (Fig. 5j, m-o). The cells within the lesions were rounded in young animals and spindle shaped in the older mice (compare, Fig. 5m-o).

Sequential induction of cardiac stress and heart failure markers in DSG2-mutant mice

The expression of well-established cardiac stress and heart failure markers $[14,16]$ was examined at 2, 8 and 13 weeks 
Table 2 Clinical measurements reveal deficiencies in right and left ventricular functions of DSG2 ${ }^{\mathrm{mt} / \mathrm{mt}}$ mutant mice

\begin{tabular}{|c|c|c|}
\hline & $\mathrm{DSG} 2^{\mathrm{wt} / \mathrm{wt}}$ & $\mathrm{DSG} 2^{\mathrm{mt} / \mathrm{mt}}$ \\
\hline$n$ & 8 & 7 \\
\hline Body weight (g) & $32.16 \pm 2.06$ & $33.89 \pm 2.69$ \\
\hline Heart weight (mg) & $174.16 \pm 16.34$ & $221.66 \pm 13.19 * * *$ \\
\hline Heart weight/body weight & $5.41 \pm 0.22$ & $6.59 \pm 0.69 * *$ \\
\hline Heart length (apex basis, mm) & $4.76 \pm 0.2$ & $5.55 \pm 0.48 * *$ \\
\hline Heart rate (beats/min) & $502.75 \pm 67.87$ & $456.83 \pm 38.45$ \\
\hline \multicolumn{3}{|l|}{ M-mode variables } \\
\hline Left ventricle (LV) mass (mg) & $115.48 \pm 24.49$ & $186.85 \pm 80.66^{*}$ \\
\hline LV mass/body mass (mg/g) & $3.57 \pm 0.65$ & $5.5 \pm 2.26^{*}$ \\
\hline Interventricular septum in diastole $(\mathrm{mm})$ & $0.71 \pm 0.07$ & $0.79 \pm 0.1$ \\
\hline LV inner diameter in diastole (mm) & $4.28 \pm 0.49$ & $5.23 \pm 1.15(P=0.05)$ \\
\hline $\mathrm{LV}$ posterior wall in diastole $(\mathrm{mm})$ & $0.73 \pm 0.18$ & $0.77 \pm 0.12$ \\
\hline Interventricular septum in systole (mm) & $1.01 \pm 0.13$ & $0.90 \pm 0.12$ \\
\hline LV inner diameter in systole (mm) & $2.68 \pm 0.48$ & $4.39 \pm 1.23 * *$ \\
\hline LV posterior wall in systole (mm) & $1.12 \pm 0.34$ & $0.98 \pm 0.18$ \\
\hline Fractional shortening $(\%)$ & $37.77 \pm 4.59$ & $16.98 \pm 5.19 * * *$ \\
\hline \multicolumn{3}{|l|}{ B-mode variables } \\
\hline Ejection fraction $(\%)$ & $67.00 \pm 5.18$ & $34.43 \pm 11.28 * * *$ \\
\hline Cardiac output (ml/min) & $24.73 \pm 3.57$ & $17.43 \pm 2.79 * *$ \\
\hline Stroke volume $(\mu \mathrm{l})$ & $50.81 \pm 7.51$ & $37.97 \pm 6.67 * *$ \\
\hline Fractional area change $(\%)$ & $52.46 \pm 8.48$ & $23.82 \pm 8.83 * * *$ \\
\hline End-diastolic volume $(\mu \mathrm{l})$ & $76.33 \pm 14.41$ & $121.82 \pm 49.70^{*}$ \\
\hline End-systolic volume $(\mu \mathrm{l})$ & $26.61 \pm 8.89$ & $83.85 \pm 48.17 * *$ \\
\hline End-diastolic volume index $(\mu \mathrm{l} / \mathrm{g})$ & $2.37 \pm 0.44$ & $3.61 \pm 1.47^{*}$ \\
\hline End-systolic volume index $(\mu 1 / g)$ & $0.82 \pm 0.26$ & $2.49 \pm 1.4 * * *$ \\
\hline \multicolumn{3}{|l|}{ Doppler wave form } \\
\hline Mitral valve E-wave peak (cm/s) & $785.64 \pm 105.67$ & $739.62 \pm 153.82(P=0,05)$ \\
\hline Mitral valve A-wave peak (cm/s) & $557.31 \pm 144.52$ & $244.25 \pm 135.75^{* *}$ \\
\hline Mitral valve E/A & $1.46 \pm 0.27$ & $3.77 \pm 2.01 * * *$ \\
\hline \multicolumn{3}{|l|}{ Invasive hemodynamics } \\
\hline Left ventricular developed pressure (LVDP) baseline & $104.00 \pm 3.81$ & $92.71 \pm 5.57 * *$ \\
\hline $\mathrm{LVDP}_{\text {norepinephrine }}$ & $120.00 \pm 7.95$ & $105.99 \pm 9.66^{*}$ \\
\hline$+\mathrm{d} P / \mathrm{d} t_{\max }$ baseline & $13,568.75 \pm 865.77$ & $9,522.14 \pm 1,778.36^{* * *}$ \\
\hline$+\mathrm{d} P / \mathrm{d} t_{\max }$ norepinephrine & $16,959.37 \pm 1,311.36$ & $11,916.14 \pm 2,293.64 * * *$ \\
\hline$-\mathrm{d} P / \mathrm{d} t_{\min }$ baseline & $-9,147.13 \pm 1,209.85$ & $-6,376.58 \pm 927.54 * *$ \\
\hline$-\mathrm{d} P / \mathrm{d} t_{\min }$ norepinephrine & $-9,958.25 \pm 1,293.03$ & $-7,450.29 \pm 1,218.84 * *$ \\
\hline Relaxation index $x_{\text {baseline }}$ & $-87.92 \pm 10.81$ & $-68.50 \pm 6.80 * *$ \\
\hline Relaxation index $x_{\text {norepinehrine }}$ & $-83.09 \pm 10.30$ & $-70.09 \pm 8.64 *$ \\
\hline
\end{tabular}

M-mode and B-mode measurements indicate left ventricular dilatation in the mutant mice accompanied by decreased systolic function (echocardiography and invasive hemodynamics). Note the decreased left ventricular compliance and impaired left atrial contractility. Late diastolic velocity was reduced with consequently increased E/A; (wild-type DSG2 ${ }^{\mathrm{wt} / \mathrm{wt}}$ vs. DSG2 ${ }^{\mathrm{mt} / \mathrm{mt}}$ mutants $* P<0.05, * * P<0.01, * * * P<0.001$; mean $\pm \mathrm{SD}$ )

by real time RT-PCR to assess the consequences of DSG2 mutation at the molecular level. At 2 weeks, cardiac connective tissue growth factor (CTGF) mRNA was significantly upregulated. In addition, growth differentiation factor 15 (GDF15) and c-myc mRNA were increased
(Fig. 7). When 2-week-old DSG2 ${ }^{\mathrm{mt} / \mathrm{mt}}$ mice were further subclassified by visual inspection into those without and those with fibrotic lesions, significantly elevated GDF15 mRNA expression was found in the hearts with fibrotic lesions $(3.83 \pm 1.42$ vs. $0.18 \pm 0.03$ arbitrary units; 
Fig. 2 Homozygous DSG2mutant mice $\left(\mathrm{DSG} 2^{\mathrm{mt}}\right.$ ) present ventricular dilation and signs of compromised cardiac function. a, b Representative echocardiography (pictures taken in B-mode) at the end of diastole in wild-type (DSG2 ${ }^{\mathrm{wt}}$ ) male mice compared to agematched male $\mathrm{DSG} 2^{\mathrm{mt}}$ mice. $R V$ right ventricle, $L V$ left ventricle, IVS interventricular septum, $L V P W$ left ventricular posterior wall, $L V I D$ left ventricular inner diameter, ao aorta, $p m$ papillary muscle. c, $\mathbf{d}$ Comparison of the morphology of a wild-type

(c) and a DSG2-mutant heart (d), which presents an enlarged right ventricle and extensive fibrotic lesions (arrows). e, f Representative ECGs from wild-type (e) and mutant mice (f). Note the abnormalities in the ECGs of the mutant mice presenting extrasystole, arrthythmia and conduction abnormalities (f, from top to bottom)
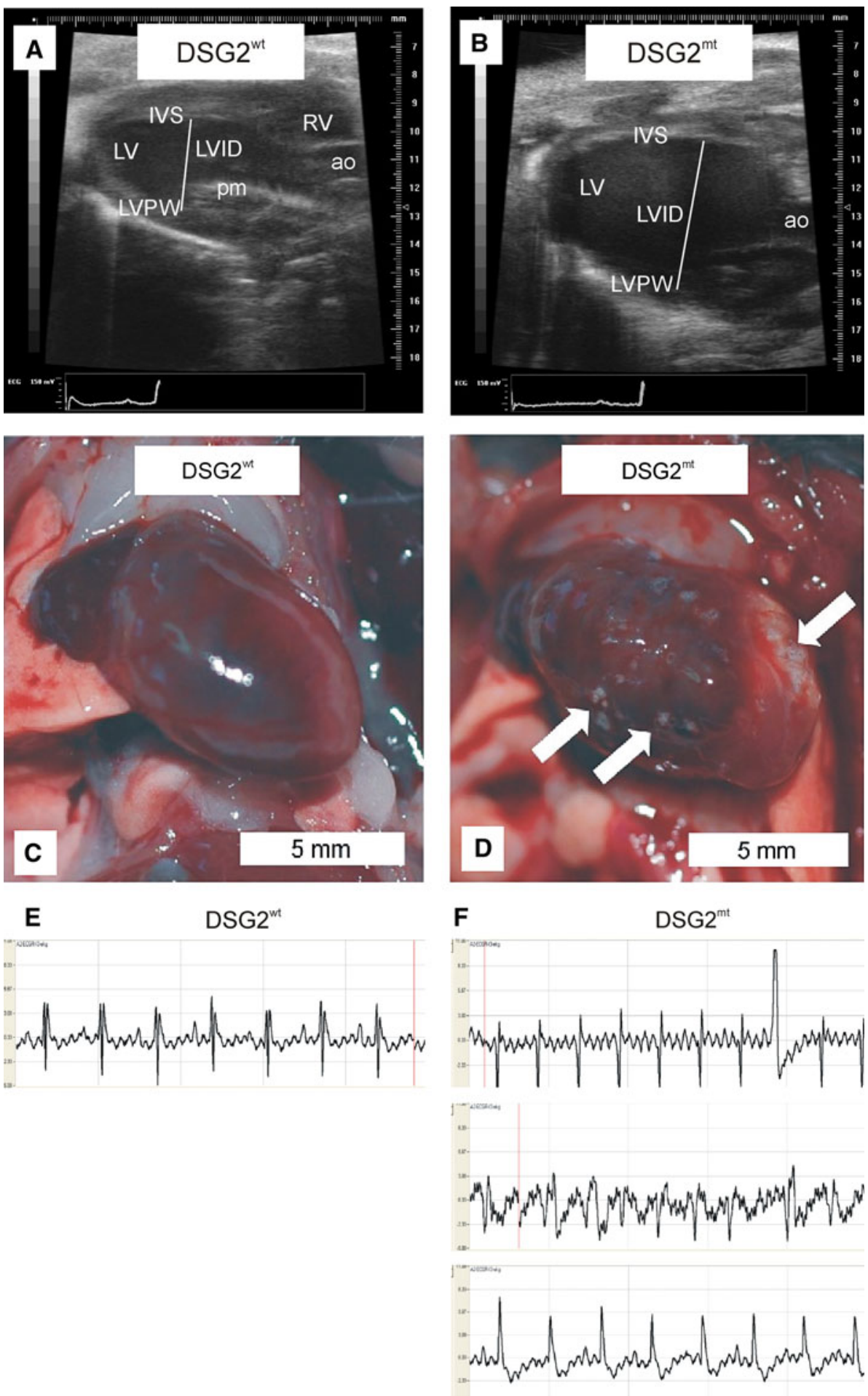

Table 3). This suggests that GDF15 mRNA expression is an early indicator of disease progression.

At 8 and 13 weeks, CTGF, GDF15 and c-myc mRNA are all significantly upregulated in the mutant animals (Fig. 7). In addition, the mRNA of atrial natriuretic peptide (ANF) and B-type natriuretic factor (BNF), which were not any different from the wild type at 2 weeks, were also significantly increased in DSG2 $2^{\mathrm{mt} / \mathrm{mt}}$ mice at these later time points (Fig. 7). Furthermore, cardiac $\beta$-myosin heavy chain ( $\beta$ MHC) mRNA, a marker of the fetal gene program [54], was found to be significantly upregulated in DSG2 $2^{\mathrm{mt} / \mathrm{mt}}$ mice at 8 weeks $(0.18 \pm 0.04$ vs. $1.58 \pm 0.52$ arbitrary 
Fig. 3 Cardiac morphology and histology of 13-week-old male $\mathrm{DSG} 2^{\mathrm{mt} / \mathrm{mt}}$ mice. Note the pronounced dilation of the heart chambers in (a, b) and the dilated atria (arrows in a). c Representative Kossa stain of an area in the ventricular wall marked by rectangles in $\mathbf{b}$. The black silver deposits within such a fibrotic lesion indicate the presence of calcified, necrotic cardiomyocytes.

d Representative hematoxylin/ eosin stain of an area with cardiomyocytes surrounded by fibrous tissue. Note the dysmorphic nuclei of cardiomyocytes (arrowheads) adjacent to fibrocytes. Scale bars: $5 \mathrm{~mm}$ in a, same magnification in $\mathbf{b} ; 200 \mu \mathrm{m}$ in $\mathbf{c}$, same magnification in $\mathbf{d}$
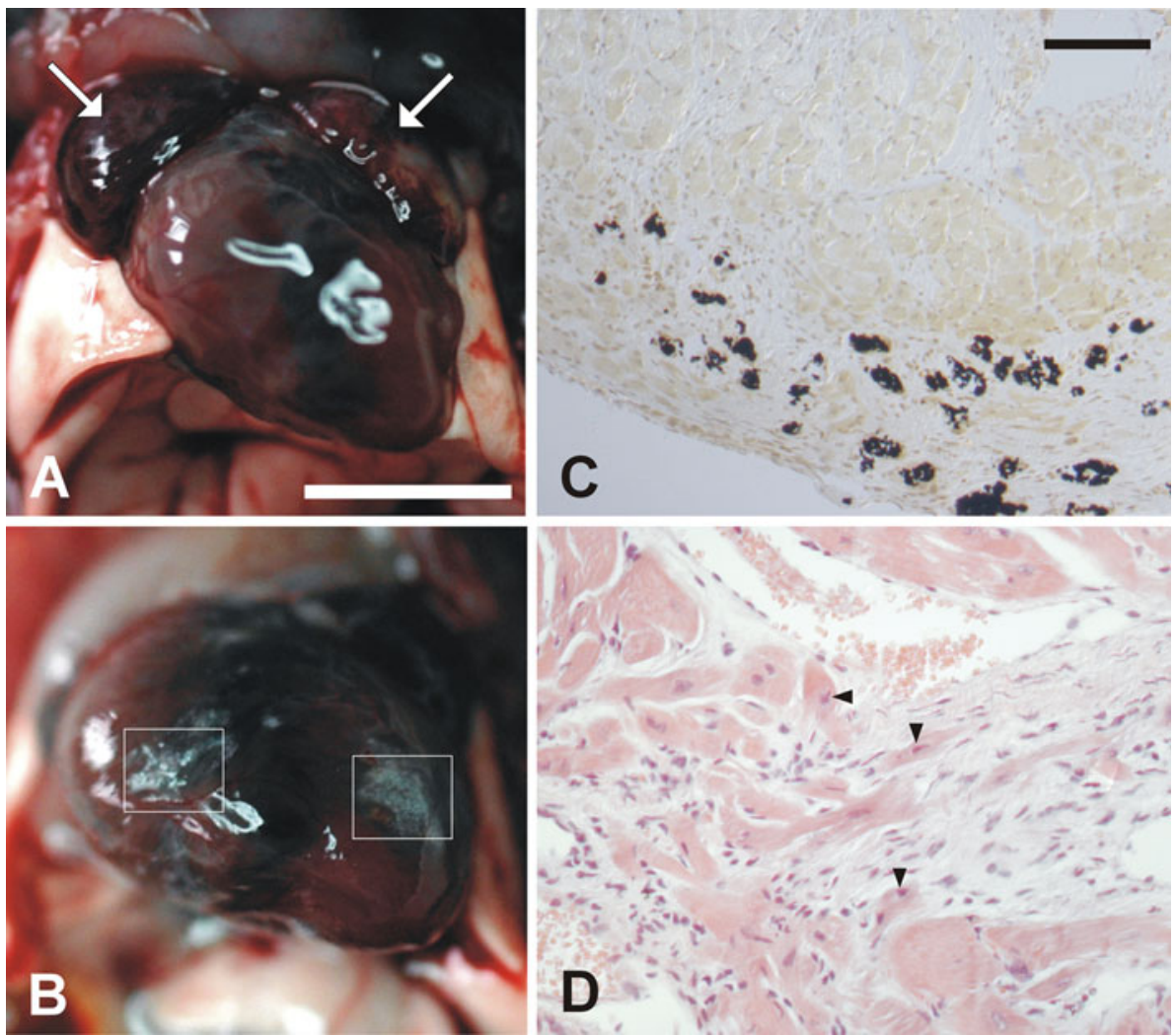

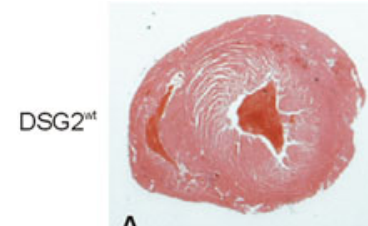

A

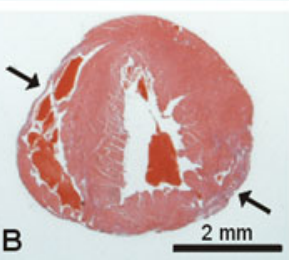

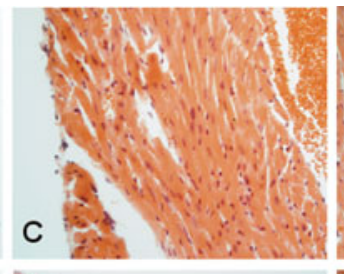

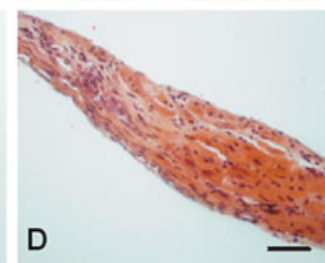

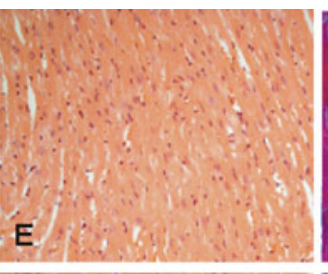
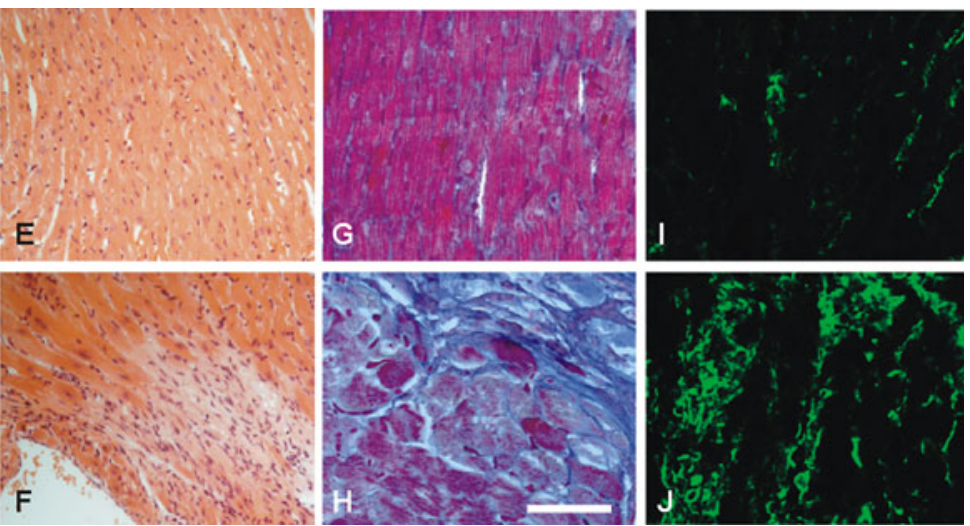

Fig. 4 DSG2 mutation induces fibrosis in both ventricles. Hearts were dissected from wild-type and mutant mice carrying two DSG2 ${ }^{\mathrm{mt}}$ alleles. Histological sections were either stained with hematoxylin/ eosin $(\mathbf{a}-\mathbf{f})$ and azan $(\mathbf{g}, \mathbf{h})$ or were incubated with antibodies directed against the connective tissue marker vimentin and processed for

units; $P=0.0555)$ and 13 weeks $(1.45 \pm 0.06$ vs. $2.51 \pm$ 0.29 arbitrary units; $P=0.0095$ ). In contrast, cardiac RGS2 mRNA expression did not differ or tended to be lower in mutants at the studied ages (Fig. 7). mRNA expression of the various markers was not different between wild-type and heterozygous mutant animals at 8 and 13 weeks, which was in line with the absence of changes in morphology and proliferation (e.g., Fig. 5). indirect immunofluorescence microscopy $(\mathbf{i}, \mathbf{j})$. Note the increased presence of connective tissue in $\mathrm{DSG} 2^{\mathrm{mt} / \mathrm{mt}}$ mice. In addition to diffuse fibrosis, large fibrotic scars are visible in the ventricular walls (arrows in b). The magnification is the same in $\mathbf{a}$ and $\mathbf{b}, \mathbf{c}-\mathbf{f}$ (scale bar in $\mathbf{d}, 100 \mu \mathrm{m}$ ) and $\mathbf{g}-\mathbf{j}$ (scale bar in $\mathbf{h}, 100 \mu \mathrm{m}$ )

\section{Discussion}

$\mathrm{DSG} 2^{\mathrm{mt} / \mathrm{mt}}$ mice, which lack major parts of the adhesive extracellular domains EC1 and EC2, develop cardiac fibrosis, ventricular dilation, arrhythmia and cardiac insufficiency. In other Dsg2-producing tissues such as intestinal mucosa, liver and endometrium no overt pathological alterations were observed. Yet, the majority of 

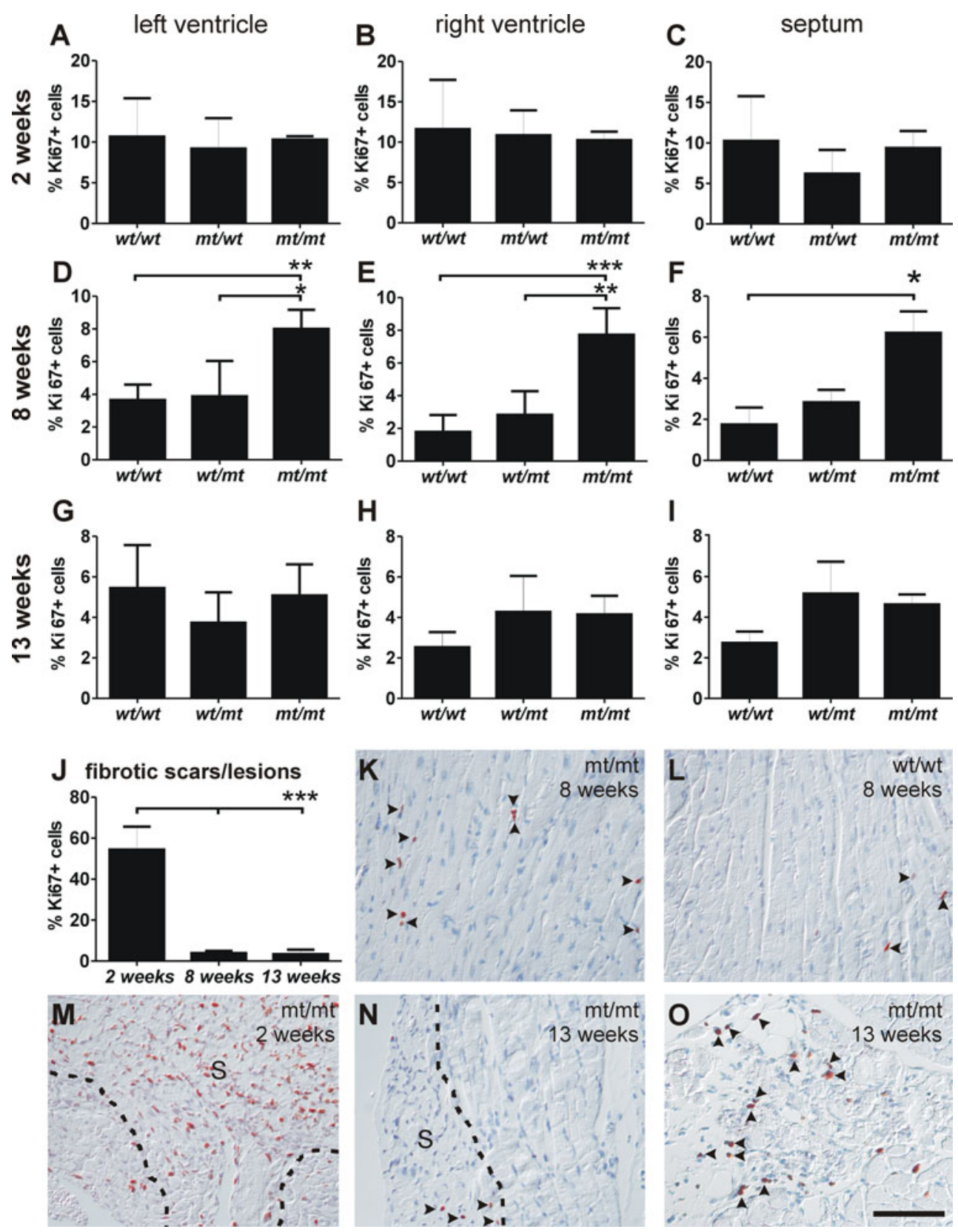

Fig. 5 Proliferation (Ki67 immunohistochemistry) of interstitial cells is transiently increased in 8-week-old DSG2 ${ }^{\mathrm{mt} / \mathrm{mt}}$ mice and in fibrotic lesions of young mutant animals. The data in $\mathbf{a}-\mathbf{j}$ (mean \pm SEM) were obtained from three to four animals from parallel breedings at each time point. At the age of 2 weeks only two $\mathrm{mt} / \mathrm{mt}$ animals were available for sampling from left and right ventricles because of large fibrotic foci in the ventricular wall. Proliferation of interstitial cells detected by Ki67 immunohistochemistry in 2- (a-c) and 13-week-old mice (g-i) was not significantly different between wild-type (wt/wt), heterozygous (wt/mt) and homozygous mutant animals $(\mathrm{mt} / \mathrm{mt})$. Results of ANOVA: a $P=0.8729$, b $P=0.9394$, c $P=0.3574$, g $P=0.4773$, h $P=0.3932$, i $P=0.2726$. d-f In 8 -week-old

mutants do not survive until birth and we are presently trying to identify the critical developmental stages. Of note, all mutants that were born displayed normal heart morphology and all of them developed the described cardiac
$\mathrm{DSG} 2^{\mathrm{mt} / \mathrm{mt}}$ mice, proliferation of interstitial cells is significantly elevated compared to wild-type animals $(* P<0.05 ; * * P<0.01$; $* * * P<0.001 ;$ ANOVA and post hoc Bonferroni tests). $\mathbf{j}$ The histogram shows that the number of Ki67-positive cells in fibrotic lesions is significantly higher in 2-week-old DSG2 ${ }^{\mathrm{mt} / \mathrm{mt}}$ mice than in 8 - and 13-week-old mutant mice $(* * * P<0.001)$. k, $\mathbf{l}$ Comparison of Ki67-staining in septum of 8-week-old DSG2 ${ }^{\mathrm{mt} / \mathrm{mt}}(\mathbf{k})$ and DSG2 $2^{\mathrm{wt} / \mathrm{wt}}$ (l). Lesion of a 2-week-old (m) and a 13-week-old DSG2 ${ }^{\mathrm{mt} / \mathrm{mt}}$ mouse (n; $S$ scar). o Small fibrotic foci with an increased number of Ki67positive cells were observed occasionally in 8- to 13-week-old mutants. Arrowheads in $\mathbf{k}, \mathbf{l}, \mathbf{n}$ and $\mathbf{o}$ mark Ki67-positive cells. Scale bar in $\mathbf{o}, 100 \mu \mathrm{m}$ (same magnification in $\mathbf{k}-\mathbf{0}$ )

phenotype. These DSG2 ${ }^{\mathrm{mt} / \mathrm{mt}}$ mice expand currently available murine models of desmosome-related dilative cardiomyopathy (DCM) and ARVC [18, 33, 47, 65]. They allow, for the first time, to study the consequences of a 

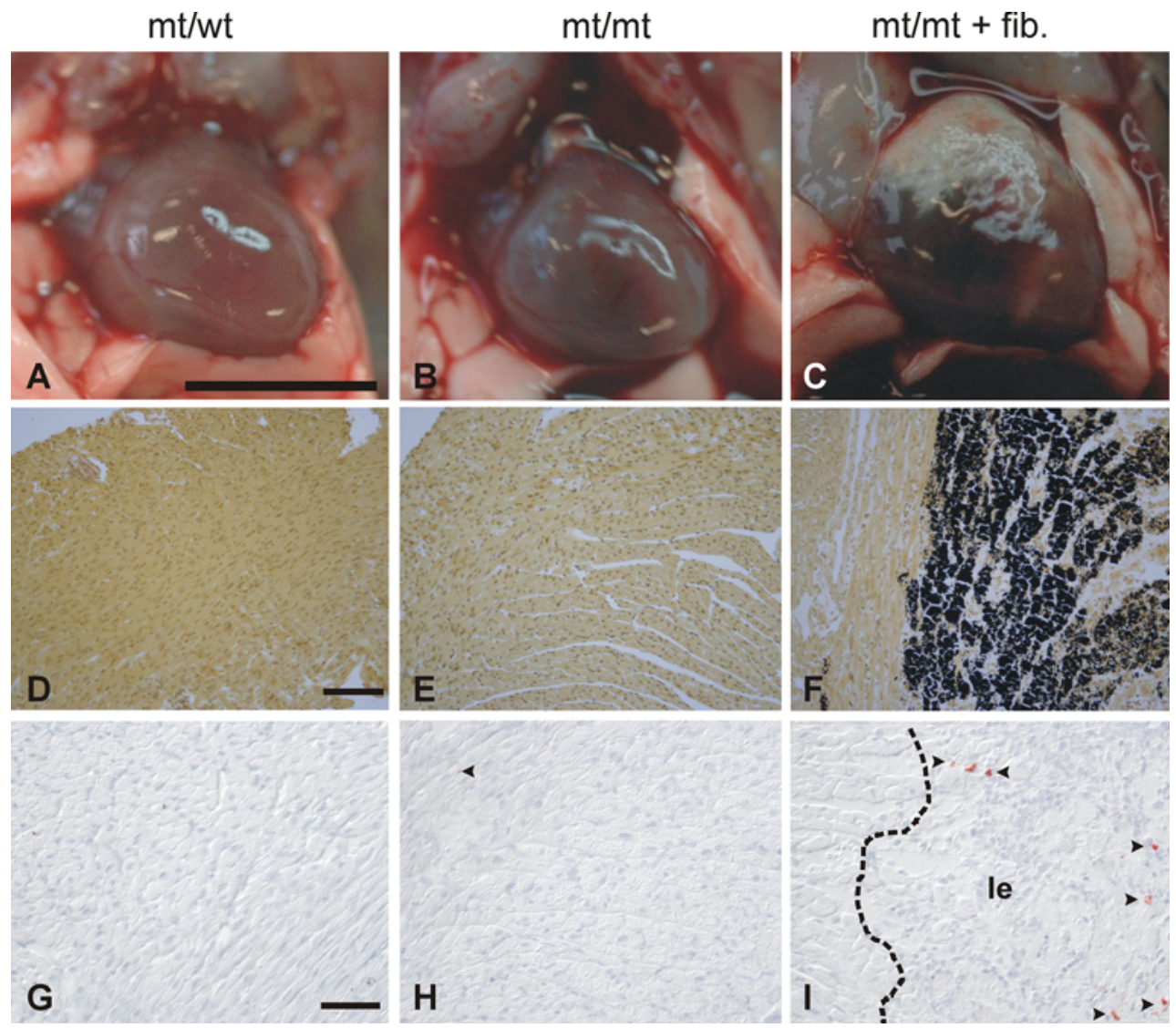

Fig. 6 Two-week-old DSG2 $2^{\mathrm{mt} / \mathrm{mt}}$ mice present variable cardiac phenotypes. In situ images of hearts (a-c), Kossa stains of histological sections (d-f) and cleaved caspase 3-immunohistology (g-i) are shown for heterozygous DSG2 $2^{\mathrm{mt} / \mathrm{wt}}$ mice $(\mathbf{a}, \mathbf{d}, \mathbf{g})$ and for homozygous $\mathrm{DSG} 2^{\mathrm{mt} / \mathrm{mt}}$ mice either without visible fibrotic foci $(\mathbf{b}, \mathbf{e}, \mathbf{f})$ or with extensive fibrotic lesions (+fib.; c, f, i). Note the positive Kossa reaction in the large fibrotic area in (f) and the increase of cleaved caspase-3 positive cells (arrowheads) within a fibrotic lesion (le; i) of a DSG2 ${ }^{\mathrm{mt} / \mathrm{mt}}$ mouse with fibrosis. Scale bars: $5 \mathrm{~mm}$ in a (same magnification in $\mathbf{b}, \mathbf{c}), 200 \mu \mathrm{m}$ in (d) (same magnification in $\mathbf{e}, \mathbf{f}$ ), $100 \mu \mathrm{m}$ in (g) (same magnification in $\mathbf{h}, \mathbf{i}$ )

significantly elevated ER- or Golgi localization of the mutant Dsg2 in comparison to its wild-type counterpart [27]. Although the conserved aminoterminal "tryptophane 2 ", which has been implicated in cis and trans interactions in other cadherins, is still present in the mutant Dsg2, its hydrophobic binding pocket is deleted (cf. [59]). Other amino acids that are probably involved in cadherin-cadherin interactions are also missing [7, 52, 59]. Most importantly, the overall shortening of the extracellular domains in combination with the loss of calcium binding, which is presumably involved in stabilization of the EC domains [42, 44, 52], is expected to lead to reduced EC domain overlap for homophilic cis and trans interactions [7, 10, 28, 52, 59]. Heterophilic interactions with desmocollin 2 may be affected in a similar way. Taken together, decreased transcellular flexibility and adhesion would be expected in tissues producing the mutant Dsg2. Further in vivo evidence for the importance of the EC1/EC2 domains can be derived from observations in human diseases. Thus, the deleted Dsg2 domains contain epitopes corresponding 
Fig. 7 Markers of heart failure are increased in DSG2 $2^{\mathrm{mt} / \mathrm{mt}}$ mice. Cardiac ANF, BNF, c-myc, CTGF and GDF15 mRNA expression was assessed by real time RT-PCR in 2-, 8- and 13-week-old DSG2 ${ }^{\mathrm{wt} / \mathrm{wt}}$, $\mathrm{DSG} 2^{\mathrm{wt} / \mathrm{mt}}$ and DSG2 ${ }^{\mathrm{mt} / \mathrm{mt}}$ mice. Each column summarizes the data of three to seven animals (mean \pm SEM).

Hydroxymethylbilane synthase (HMBS) was used as

housekeeping gene control. Unaltered regulator of $\mathrm{G}$ protein signaling 2 (RGS2) mRNA expression rules out a systematic error of the RT-PCR $(\mathbf{p}-\mathbf{r})$. Results of the post hoc Bonferroni tests: $* P<0.05$, $* * P<0.01, * * * P<0.001$. Statistical analysis of mRNA expression data showing no significant differences:

a $P=0.3409 ; \mathbf{d} P=0.0812$;

g $P=0.1055 ; \mathbf{m} P=0.1466$;

p $P=0.820 ; \mathbf{q} P=0.1837$;

r $P=0.1623$
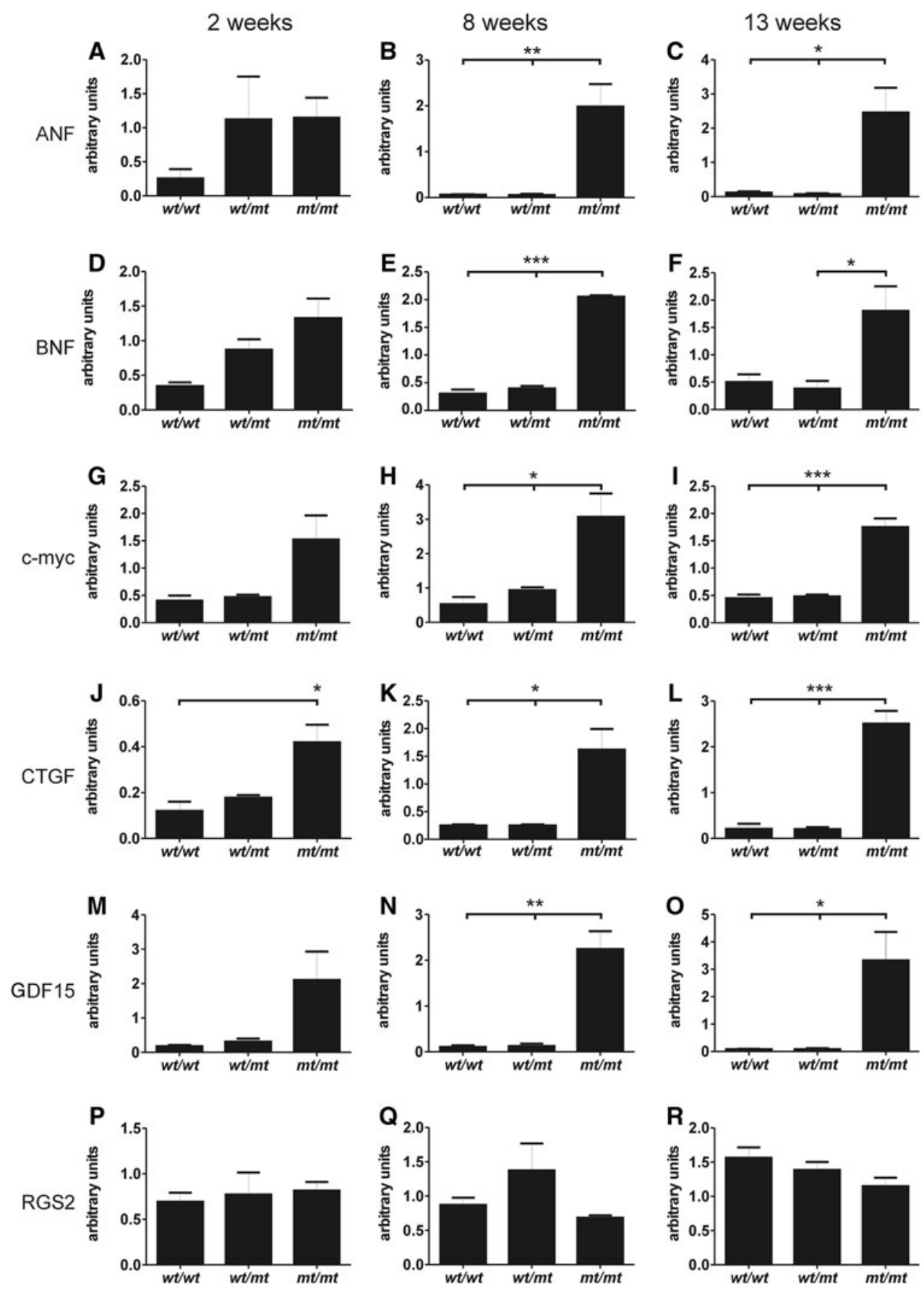

to regions of epidermal desmoglein 3 that are targeted by pemphigus autoimmune antibodies, which disrupt epidermal cell-cell adhesion [25, 62]. The reduced adhesiveness of Dsg2 ${ }^{\mathrm{mt}}$ and the decreased desmosomal localization of Dsg2 ${ }^{\mathrm{mt}}$ may therefore weaken intercalated discs and lead to impaired force transmission making mutant hearts more susceptible to microtraumata. Dsgs, however, also fulfill functions in signaling. Thus, blockade of specific Dsg1 and 3 epitopes, which correspond to the region deleted in our Dsg2 mutants, by pemphigus autoantibodies affects signaling pathways involving $\mathrm{p} 38$, RhoA, protein kinase $\mathrm{C} \alpha$ and cdk-2 in skin [6, 11, 36, 63]. Furthermore, loss of desmosomal cadherins and associated proteins interferes with wnt/ $\beta$-catenin signaling $[18,28]$, which has been implicated in DCM [26]. Further investigations are needed to clarify the exact mechanism(s).

The DSG $2^{\mathrm{mt} / \mathrm{mt}}$ mice helped to identify details of cardiac disease before macroscopic and microscopic alterations became apparent. Thus, c-myc and CTGF mRNAs were already increased in 2-week-old mutant mice with 
Table 3 Cardiac cytokine mRNA expression in relation to fibrosis in 2-week-old DSG2-mutant mice

\begin{tabular}{|c|c|c|c|c|c|}
\hline Cytokine mRNA & $\mathrm{wt} / \mathrm{wt}(n=3)$ & $\mathrm{mt} / \mathrm{wt}(n=4)$ & $\mathrm{mt} / \mathrm{mt}-$ fibr. $(n=4)$ & $\mathrm{mt} / \mathrm{mt}+$ fibr. $(n=3)$ & ANOVA \\
\hline ANF & $0.26 \pm 0.14$ & $1.12 \pm 0.63$ & $0.64 \pm 0.25$ & $1.82 \pm 0.27$ & 0.1371 \\
\hline $\mathrm{BNF}$ & $0.34 \pm 0.05$ & $0.87 \pm 0.15$ & $1.13 \pm 0.32$ & $1.59 \pm 0.54$ & 0.1196 \\
\hline c-myc & $0.40 \pm 0.09$ & $0.47 \pm 0.04$ & $1.14 \pm 0.48$ & $2.04 \pm 0.81$ & 0.1006 \\
\hline CTGF & $0.12 \pm 0.04$ & $0.18 \pm 0.01$ & $0.34 \pm 0.07$ & $0.53 \pm 0.15^{*}$ & 0.0191 \\
\hline GDF15 & $0.18 \pm 0.03$ & $0.31 \pm 0.09$ & $0.82 \pm 0.30$ & $3.83 \pm 1.42^{* * * *,+}$ & 0.0083 \\
\hline RGS2 & $0.69 \pm 0.10$ & $0.77 \pm 0.24$ & $0.85 \pm 0.15$ & $0.76 \pm 0.07$ & 0.9015 \\
\hline
\end{tabular}

The results of cytokine RT-PCR analyses in hearts of wild-type (wt/wt), heterozygous $(\mathrm{mt} / \mathrm{wt})$ and homozygous DSG2-mutant mice (mt/mt) are summarized. The homozygous mutant mice are further subclassified into those with severe cardiac fibrosis (mt/mt + fibr.) and those without visible cardiac fibrosis ( $\mathrm{mt} / \mathrm{mt}-$ fibr.). Data are given as mean \pm SEM. Note the significantly elevated GDF15 mRNA in the homozygous mutant animals with fibrotic foci

$* \mathrm{wt} / \mathrm{wt}$ versus $\mathrm{mt} / \mathrm{mt}+$ fibr. $P<0.05$

** $\mathrm{mt} / \mathrm{wt}$ versus $\mathrm{mt} / \mathrm{mt}+$ fibr. $P<0.05$

$+\mathrm{mt} / \mathrm{mt}-$ fibr. versus $\mathrm{mt} / \mathrm{mt}+$ fibr. $P<0.05$

seemingly normal heart muscle indicating early compensatory reactions of the heart to DSG2 gene mutation. In accordance, it has been reported that c-myc and CTGF are involved in the regulation of the cardiac hypertrophic response and cardiac remodeling upon cardiac stress [16, $29,35,45]$. In the presence of overt cardiomyocyte death and fibrosis, GDF15 mRNA expression was also found to be significantly elevated in 2-week-old mutants. GDF15 is a reliable marker of heart failure in humans [31] and exerts antihypertrophic and cardioprotective effects [32, 64]. This observation can be taken as an indication of a later step of disease progression, whereby altered cardiac wall compliance is compensated for in addition to Dsg2 malfunction. Disease progression and cardiac response were reflected by further increase of the cardiac stress marker mRNAs and the onset of mRNA synthesis of the natriuretic peptides $\mathrm{ANF}$ and BNF in 8-week mutant animals, all of which showed fibrosis and cardiomyocyte death. ANF and BNF effect diuresis and vasodilation and exert an antifibrotic activity in the heart [41, 43].

The fibrotic response in the DSG2 $2^{\mathrm{mt} / \mathrm{mt}}$ mice could be subdivided into interstitial fibrosis affecting the entire heart muscle and focal fibrosis or scarring. Interstitial cell proliferation subsides in wild-type animals at 8 weeks, when the heart reaches maturity [37]. In mutant mice, however, the decline of interstitial cell proliferation rate was postponed to the age of 13 weeks. The prolonged interstitial cell proliferation may be a compensation for the compromised Dsg2 function in force transmission at the intercalated discs. In contrast to interstitial fibrosis, fibrotic foci were characterized early on by Kossa-positive cardiomyocytes indicative of necrotic calcinosis [34]. These foci appear in bursts during disease progression and were observed as early as 2 weeks after birth and also later on. Interestingly, similar cardiac necrosis was also described in mice overexpressing a mutant human DSG2 gene [47]. These fibrotic bursts may be induced by local injuries of the heart muscle, which result initially in local increase of fibroblast proliferation and are coupled to increased apoptosis as evidenced by elevated cleaved caspase 3-staining and abundant cardiomyocyte necrosis. Our findings further suggest that these active replacement processes were terminated by the formation of inactive scar tissue that was abundant in the older mutants. It will be interesting to find out whether the peculiar patterns of fibrosis can be correlated with the complex cardiac fiber orientation and force distribution fields [30]. The pronounced histomorphological alterations in cardiac architecture lead to increased wall stiffness and are responsible for the right ventricular dilation that was observed at autopsy and the pathological echocardiographic findings of left ventricular dilation in combination with systolic and diastolic dysfunction. Biventricular dilation probably plays a major part in triggering arrhythmias leading to premature death.

Taken together, the DSG2 ${ }^{\mathrm{mt} / \mathrm{mt}}$ mice revealed major features of desmosome-related cardiomyopathies. Further assessment will clarify steps of disease initiation and progression and will help to develop and test therapeutic strategies for treatment of human DCM and ARVC.

Acknowledgments We wish to thank Drs. David Garrod, Gale Martin and Francis Stewart for various reagents and Diana SeelisSchmidt, Ursula Disque-Kaiser, Ursula Kirmair and Vanessa Creutz for expert technical assistance. We also want to thank Svetlana Ohngemach for help with blastocyst injections and embryo transfers, Rosario Heck for help with embryonal stem cell work, the animal technicians of the Medical Centers in Mainz and Aachen for their excellent animal care and Dr. Andreas Herrler for help during intermediate stages of the project. The work was supported by the Deutsche Krebshilfe and the German Research Council (LE 566/11-1 to REL, Mc1821/3-1 to MWM). 


\section{References}

1. Al-Amoudi A, Diez DC, Betts MJ, Frangakis AS (2007) The molecular architecture of cadherins in native epidermal desmosomes. Nature 450:832-837. doi:10.1038/nature05994

2. Awad MM, Calkins H, Judge DP (2008) Mechanisms of disease: molecular genetics of arrhythmogenic right ventricular dysplasia/ cardiomyopathy. Nat Clin Pract Cardiovasc Med 5:258-267. doi: 10.1038/ncpcardio1182

3. Basso C, Corrado D, Marcus FI, Nava A, Thiene G (2009) Arrhythmogenic right ventricular cardiomyopathy. Lancet 373:1289-1300. doi:10.1016/S0140-6736(09)60256-7

4. Basso C, Czarnowska E, Della Barbera M, Bauce B, Beffagna G, Wlodarska EK, Pilichou K, Ramondo A, Lorenzon A, Wozniek O, Corrado D, Daliento L, Danieli GA, Valente M, Nava A, Thiene G, Rampazzo A (2006) Ultrastructural evidence of intercalated disc remodelling in arrhythmogenic right ventricular cardiomyopathy: an electron microscopy investigation on endomyocardial biopsies. Eur Heart J 27:1847-1854. doi:10.1093/ eurheartj/ehl095

5. Beffagna G, Occhi G, Nava A, Vitiello L, Ditadi A, Basso C, Bauce B, Carraro G, Thiene G, Towbin JA, Danieli GA, Rampazzo A (2005) Regulatory mutations in transforming growth factor-beta3 gene cause arrhythmogenic right ventricular cardiomyopathy type 1. Cardiovasc Res 65:366-373. doi: 10.1016/j.cardiores.2004.10.005

6. Berkowitz P, Chua M, Liu Z, Diaz LA, Rubenstein DS (2008) Autoantibodies in the autoimmune disease pemphigus foliaceus induce blistering via p38 mitogen-activated protein kinasedependent signaling in the skin. Am J Pathol 173:1628-1636. doi: 10.2353/ajpath.2008.080391

7. Boggon TJ, Murray J, Chappuis-Flament S, Wong E, Gumbiner BM, Shapiro L (2002) C-cadherin ectodomain structure and implications for cell adhesion mechanisms. Science 296:13081313. doi:10.1126/science. 1071559

8. Buchholz F, Angrand PO, Stewart AF (1998) Improved properties of FLP recombinase evolved by cycling mutagenesis. Nat Biotechnol 16:657-662. doi:10.1038/nbt0798-657

9. Calkins H, Marcus F (2008) Arrhythmogenic right ventricular cardiomyopathy/dysplasia: an update. Curr Cardiol Rep $10: 367-375$

10. Chappuis-Flament S, Wong E, Hicks LD, Kay CM, Gumbiner BM (2001) Multiple cadherin extracellular repeats mediate homophilic binding and adhesion. J Cell Biol 154:231-243

11. Chernyavsky AI, Arredondo J, Kitajima Y, Sato-Nagai M, Grando SA (2007) Desmoglein versus non-desmoglein signaling in pemphigus acantholysis: characterization of novel signaling pathways downstream of pemphigus vulgaris antigens. J Biol Chem 282:13804-13812. doi:10.1074/jbc.M611365200

12. Chitaev NA, Averbakh AZ, Troyanovsky RB, Troyanovsky SM (1998) Molecular organization of the desmoglein-plakoglobin complex. J Cell Sci 111(Pt 14):1941-1949

13. Chitaev NA, Troyanovsky SM (1997) Direct Ca2+-dependent heterophilic interaction between desmosomal cadherins, desmoglein and desmocollin, contributes to cell-cell adhesion. J Cell Biol 138:193-201

14. Dorn GW 2nd, Robbins J, Sugden PH (2003) Phenotyping hypertrophy: eschew obfuscation. Circ Res 92:1171-1175. doi: 10.1161/01.RES.0000077012.11088.BC

15. Eshkind L, Tian Q, Schmidt A, Franke WW, Windoffer R, Leube RE (2002) Loss of desmoglein 2 suggests essential functions for early embryonic development and proliferation of embryonal stem cells. Eur J Cell Biol 81:592-598

16. Frank D, Kuhn C, Brors B, Hanselmann C, Ludde M, Katus HA, Frey N (2008) Gene expression pattern in biomechanically stretched cardiomyocytes: evidence for a stretch-specific gene program. Hypertension 51:309-318. doi:10.1161/HYPERTENSION AHA.107.098046

17. Fressart V, Duthoit G, Donal E, Probst V, Deharo JC, Chevalier P, Klug D, Dubourg O, Delacretaz E, Cosnay P, Scanu P, Extramiana F, Keller D, Hidden-Lucet F, Simon F, Bessirard V, Roux-Buisson N, Hebert JL, Azarine A, Casset-Senon D, Rouzet F, Lecarpentier Y, Fontaine G, Coirault C, Frank R, Hainque B, Charron P (2010) Desmosomal gene analysis in arrhythmogenic right ventricular dysplasia/cardiomyopathy: spectrum of mutations and clinical impact in practice. Europace 12:861-868. doi: 10.1093/europace/euq104

18. Garcia-Gras E, Lombardi R, Giocondo MJ, Willerson JT, Schneider MD, Khoury DS, Marian AJ (2006) Suppression of canonical Wnt/beta-catenin signaling by nuclear plakoglobin recapitulates phenotype of arrhythmogenic right ventricular cardiomyopathy. J Clin Invest 116:2012-2021. doi:10.1172/ JCI27751

19. Garrod D, Chidgey M (2008) Desmosome structure, composition and function. Biochim Biophys Acta 1778:572-587. doi: 10.1016/j.bbamem.2007.07.014

20. Gerull B, Heuser A, Wichter T, Paul M, Basson CT, McDermott DA, Lerman BB, Markowitz SM, Ellinor PT, MacRae CA, Peters S, Grossmann KS, Drenckhahn J, Michely B, Sasse-Klaassen S, Birchmeier W, Dietz R, Breithardt G, Schulze-Bahr E, Thierfelder L (2004) Mutations in the desmosomal protein plakophilin2 are common in arrhythmogenic right ventricular cardiomyopathy. Nat Genet 36:1162-1164. doi:10.1038/ng1461

21. Green KJ, Simpson CL (2007) Desmosomes: new perspectives on a classic. J Invest Dermatol 127:2499-2515. doi:10.1038/sj.jid. 5701015

22. Harrell MD, Harbi S, Hoffman JF, Zavadil J, Coetzee WA (2007) Large-scale analysis of ion channel gene expression in the mouse heart during perinatal development. Physiol Genomics 28:273-283. doi:10.1152/physiolgenomics.00163.2006

23. He W, Cowin P, Stokes DL (2003) Untangling desmosomal knots with electron tomography. Science 302:109-113. doi:10.1126/ science. 1086957

24. Herren T, Gerber PA, Duru F (2009) Arrhythmogenic right ventricular cardiomyopathy/dysplasia: a not so rare "disease of the desmosome" with multiple clinical presentations. Clin Res Cardiol 98:141-158. doi:10.1007/s00392-009-0751-4

25. Heupel WM, Zillikens D, Drenckhahn D, Waschke J (2008) Pemphigus vulgaris IgG directly inhibit desmoglein 3-mediated transinteraction. J Immunol 181:1825-1834

26. Hirschy A, Croquelois A, Perriard E, Schoenauer R, Agarkova I, Hoerstrup SP, Taketo MM, Pedrazzini T, Perriard JC, Ehler E (2010) Stabilised beta-catenin in postnatal ventricular myocardium leads to dilated cardiomyopathy and premature death. Basic Res Cardiol 105:597-608. doi:10.1007/s00395-010-0101-8

27. Holthofer B (2007) Konditionale Mutagenese von Desmoglein 2 in der Maus. Institute of Anatomy. Johannes Gutenberg-University, Mainz, pp 1-208

28. Holthofer B, Windoffer R, Troyanovsky S, Leube RE (2007) Structure and function of desmosomes. Int Rev Cytol 264:65-163. doi:10.1016/S0074-7696(07)64003-0

29. Ihm SH, Chang K, Kim HY, Baek SH, Youn HJ, Seung KB, Kim JH (2010) Peroxisome proliferator-activated receptor-gamma activation attenuates cardiac fibrosis in type 2 diabetic rats: the effect of rosiglitazone on myocardial expression of receptor for advanced glycation end products and of connective tissue growth factor. Basic Res Cardiol 105:399-407. doi:10.1007/s00395009-0071-x

30. Kelly D, Mackenzie L, Hunter P, Smaill B, Saint DA (2006) Gene expression of stretch-activated channels and mechanoelectric 
feedback in the heart. Clin Exp Pharmacol Physiol 33:642-648. doi:10.1111/j.1440-1681.2006.04392.x

31. Kempf T, von Haehling S, Peter T, Allhoff T, Cicoira M, Doehner W, Ponikowski P, Filippatos GS, Rozentryt P, Drexler H, Anker SD, Wollert KC (2007) Prognostic utility of growth differentiation factor-15 in patients with chronic heart failure. J Am Coll Cardiol 50:1054-1060. doi:10.1016/j.jacc.2007.04.091

32. Khan SQ, Ng K, Dhillon O, Kelly D, Quinn P, Squire IB, Davies JE, Ng LL (2009) Growth differentiation factor-15 as a prognostic marker in patients with acute myocardial infarction. Eur Heart J 30:1057-1065. doi:10.1093/eurheartj/ehn600

33. Kirchhof P, Fabritz L, Zwiener M, Witt H, Schafers M, Zellerhoff S, Paul M, Athai T, Hiller KH, Baba HA, Breithardt G, Ruiz P, Wichter T, Levkau B (2006) Age- and training-dependent development of arrhythmogenic right ventricular cardiomyopathy in heterozygous plakoglobin-deficient mice. Circulation 114:1799-1806. doi:10.1161/CIRCULATIONAHA.106.624502

34. Korff S, Riechert N, Schoensiegel F, Weichenhan D, Autschbach F, Katus HA, Ivandic BT (2006) Calcification of myocardial necrosis is common in mice. Virchows Arch 448:630-638. doi: 10.1007/s00428-005-0071-7

35. Kroumpouzou E, Gomatos IP, Kataki A, Karayannis M, Dangas GD, Toutouzas P (2003) Common pathways for primary hypertrophic and dilated cardiomyopathy. Hybrid Hybridomics 22:41-45. doi:10.1089/153685903321538071

36. Lanza A, Cirillo N, Rossiello R, Rienzo M, Cutillo L, Casamassimi A, de Nigris F, Schiano C, Rossiello L, Femiano F, Gombos F, Napoli C (2008) Evidence of key role of Cdk2 overexpression in pemphigus vulgaris. $\mathrm{J}$ Biol Chem 283:8736-8745. doi:10.1074/jbc.M702186200

37. Leu M, Ehler E, Perriard JC (2001) Characterisation of postnatal growth of the murine heart. Anat Embryol (Berl) 204:217-224

38. Lewandoski M, Martin GR (1997) Cre-mediated chromosome loss in mice. Nat Genet 17:223-225. doi:10.1038/ng1097-223

39. Merner ND, Hodgkinson KA, Haywood AF, Connors S, French VM, Drenckhahn JD, Kupprion C, Ramadanova K, Thierfelder L, McKenna W, Gallagher B, Morris-Larkin L, Bassett AS, Parfrey PS, Young TL (2008) Arrhythmogenic right ventricular cardiomyopathy type 5 is a fully penetrant, lethal arrhythmic disorder caused by a missense mutation in the TMEM43 gene. Am J Hum Genet 82:809-821. doi:10.1016/j.ajhg.2008.01.010

40. Merx MW, Schafer C, Westenfeld R, Brandenburg V, Hidajat S, Weber C, Ketteler M, Jahnen-Dechent W (2005) Myocardial stiffness, cardiac remodeling, and diastolic dysfunction in calcification-prone fetuin-A-deficient mice. J Am Soc Nephrol 16:3357-3364. doi:10.1681/ASN.2005040365

41. Molkentin JD (2003) A friend within the heart: natriuretic peptide receptor signaling. J Clin Invest 111:1275-1277. doi: 10.1172/JCI18389

42. Nagar B, Overduin M, Ikura M, Rini JM (1996) Structural basis of calcium-induced E-cadherin rigidification and dimerization. Nature 380:360-364. doi:10.1038/380360a0

43. Nishikimi T, Maeda N, Matsuoka H (2006) The role of natriuretic peptides in cardioprotection. Cardiovasc Res 69:318-328. doi: 10.1016/j.cardiores.2005.10.001

44. Overduin M, Harvey TS, Bagby S, Tong KI, Yau P, Takeichi M, Ikura M (1995) Solution structure of the epithelial cadherin domain responsible for selective cell adhesion. Science 267:386-389

45. Panek AN, Posch MG, Alenina N, Ghadge SK, Erdmann B, Popova E, Perrot A, Geier C, Dietz R, Morano I, Bader M, Ozcelik C (2009) Connective tissue growth factor overexpression in cardiomyocytes promotes cardiac hypertrophy and protection against pressure overload. PLoS One 4:e6743. doi:10.1371/ journal.pone. 0006743
46. Pasdar M, Nelson WJ (1989) Regulation of desmosome assembly in epithelial cells: kinetics of synthesis, transport, and stabilization of desmoglein I, a major protein of the membrane core domain. J Cell Biol 109:163-177

47. Pilichou K, Remme CA, Basso C, Campian ME, Rizzo S, Barnett P, Scicluna BP, Bauce B, van den Hoff MJ, de Bakker JM, Tan HL, Valente M, Nava A, Wilde AA, Moorman AF, Thiene G, Bezzina CR (2009) Myocyte necrosis underlies progressive myocardial dystrophy in mouse dsg2-related arrhythmogenic right ventricular cardiomyopathy. J Exp Med 206:1787-1802. doi:10.1084/jem.20090641

48. Posch MG, Posch MJ, Geier C, Erdmann B, Mueller W, Richter A, Ruppert V, Pankuweit S, Maisch B, Perrot A, Buttgereit J, Dietz R, Haverkamp W, Ozcelik C (2008) A missense variant in desmoglein-2 predisposes to dilated cardiomyopathy. Mol Genet Metab 95:74-80. doi:10.1016/j.ymgme.2008.06.005

49. Rodriguez CI, Buchholz F, Galloway J, Sequerra R, Kasper J, Ayala R, Stewart AF, Dymecki SM (2000) High-efficiency deleter mice show that FLPe is an alternative to Cre-loxP. Nat Genet 25:139-140. doi:10.1038/75973

50. Schlegel N, Meir M, Heupel WM, Holthofer B, Leube RE, Waschke J (2010) Desmoglein 2-mediated adhesion is required for intestinal epithelial barrier integrity. Am J Physiol Gastrointest Liver Physiol 298:G774-G783. doi:10.1152/ajpgi.00239. 2009

51. Sen-Chowdhry S, Syrris P, McKenna WJ (2007) Role of genetic analysis in the management of patients with arrhythmogenic right ventricular dysplasia/cardiomyopathy. J Am Coll Cardiol 50:1813-1821. doi:10.1016/j.jacc.2007.08.008

52. Shapiro L, Fannon AM, Kwong PD, Thompson A, Lehmann MS, Grubel G, Legrand JF, Als-Nielsen J, Colman DR, Hendrickson WA (1995) Structural basis of cell-cell adhesion by cadherins. Nature 374:327-337. doi:10.1038/374327a0

53. Shimizu A, Ishiko A, Ota T, Saito H, Oka H, Tsunoda K, Amagai M, Nishikawa T (2005) In vivo ultrastructural localization of the desmoglein 3 adhesive interface to the desmosome mid-line. J Invest Dermatol 124:984-989. doi:10.1111/j.0022-202X. 2005.23706.x

54. Sugden PH, Clerk A (1998) Cellular mechanisms of cardiac hypertrophy. J Mol Med 76:725-746

55. Syed SE, Trinnaman B, Martin S, Major S, Hutchinson J, Magee AI (2002) Molecular interactions between desmosomal cadherins. Biochem J 362:317-327

56. Szabo P, Mann JR (1994) Expression and methylation of imprinted genes during in vitro differentiation of mouse parthenogenetic and androgenetic embryonic stem cell lines. Development 120:1651-1660

57. Thiene G, Corrado D, Basso C (2007) Arrhythmogenic right ventricular cardiomyopathy/dysplasia. Orphanet J Rare Dis 2:45. doi:10.1186/1750-1172-2-45

58. Tiso N, Stephan DA, Nava A, Bagattin A, Devaney JM, Stanchi F, Larderet G, Brahmbhatt B, Brown K, Bauce B, Muriago M, Basso C, Thiene G, Danieli GA, Rampazzo A (2001) Identification of mutations in the cardiac ryanodine receptor gene in families affected with arrhythmogenic right ventricular cardiomyopathy type 2 (ARVD2). Hum Mol Genet 10:189-194

59. Troyanovsky S (2005) Cadherin dimers in cell-cell adhesion. Eur J Cell Biol 84:225-233

60. Troyanovsky SM (1999) Mechanism of cell-cell adhesion complex assembly. Curr Opin Cell Biol 11:561-566

61. Tsatsopoulou AA, Protonotarios NI, McKenna WJ (2006) Arrhythmogenic right ventricular dysplasia, a cell adhesion cardiomyopathy: insights into disease pathogenesis from preliminary genotype-phenotype assessment. Heart 92:1720-1723. doi: 10.1136/hrt.2005.081679 
62. Tsunoda K, Ota T, Aoki M, Yamada T, Nagai T, Nakagawa T, Koyasu S, Nishikawa T, Amagai M (2003) Induction of pemphigus phenotype by a mouse monoclonal antibody against the amino-terminal adhesive interface of desmoglein 3. J Immunol $170: 2170-2178$

63. Waschke J, Spindler V, Bruggeman P, Zillikens D, Schmidt G, Drenckhahn D (2006) Inhibition of Rho A activity causes pemphigus skin blistering. J Cell Biol 175:721-727. doi:10.1083/ jcb. 200605125

64. Xu J, Kimball TR, Lorenz JN, Brown DA, Bauskin AR, Klevitsky R, Hewett TE, Breit SN, Molkentin JD (2006) GDF15/MIC-1 functions as a protective and antihypertrophic factor released from the myocardium in association with SMAD protein activation. Circ Res 98:342-350. doi:10.1161/01.RES.0000202804. 84885.d0
65. Yang Z, Bowles NE, Scherer SE, Taylor MD, Kearney DL, Ge S, Nadvoretskiy VV, DeFreitas G, Carabello B, Brandon LI, Godsel LM, Green KJ, Saffitz JE, Li H, Danieli GA, Calkins H, Marcus F, Towbin JA (2006) Desmosomal dysfunction due to mutations in desmoplakin causes arrhythmogenic right ventricular dysplasia/cardiomyopathy. Circ Res 99:646-655. doi:10.1161/01.RES. 0000241482.19382.c6

66. Zhang Y, Takagawa J, Sievers RE, Khan MF, Viswanathan MN, Springer ML, Foster E, Yeghiazarians Y (2007) Validation of the wall motion score and myocardial performance indexes as novel techniques to assess cardiac function in mice after myocardial infarction. Am J Physiol Heart Circ Physiol 292:H1187-H1192. doi:10.1152/ajpheart.00895.2006 